\title{
Live-dead comparison of benthic foraminiferal faunas from the Rhône prodelta (Gulf of Lions, NW Mediterranean): Development of a proxy for palaeoenvironmental reconstructions
}

\author{
Goineau A. ${ }^{1,{ }^{*}}$, Fontanier C. ${ }^{1}$, Mojtahid M. ${ }^{1}$, Fanget Anne-Sophie ${ }^{2}$, Bassetti Maria-Angela ${ }^{2}$, \\ Berne Serge ${ }^{2,3}$, Jorissen F. ${ }^{1}$
}

${ }^{1}$ LUNAM Université, Université d'Angers, UMR CNRS 6112 LPGN-BIAF - Laboratoire des BioIndicateurs Actuels et Fossiles, 2 Boulevard Lavoisier, 49045 Angers Cedex, France

${ }^{2}$ Univ. Perpignan Via Domitia, CEntre de Formation et de Recherche sur les Environnements Méditerranéens (CEFREM), UMR CNRS 5110, F-66860, Perpignan, France

${ }^{3}$ IFREMER, Geosciences Marines, Centre de Brest, BP70, 29280 Plouzané, France

* Corresponding author : A. Goineau, email address : A.Goineau@noc.ac.uk

\begin{abstract}
:
Dead benthic foraminiferal faunas $(>150 \mu \mathrm{m})$ from the Rhône prodelta (Gulf of Lions, NW Mediterranean) were analysed at 41 stations (15-100 m water depth) sampled in June 2005 and September 2006, and compared to the living faunas investigated during previous studies at the same stations. The comparison between dead and living assemblages enhances the understanding of taphonomic processes that may modify the composition of the dead faunas in this area. We observed a loss of individuals from living to dead assemblages of species characterised by a fairly fragile test and therefore more prone to fragmentation or dissolution (e.g., Bolivina alata, Quinqueloculina tenuicollis). Allochthonous dead and/or live specimens may be transported to some parts of the prodelta, particularly the shallowest sites where hydrodynamic processes (i.e., river flood, storm swells, longshore currents) are more intense. These specimens may originate from relict deltaic structures (e.g., Elphidium spp. from the lobe of Bras de Fer) or from surrounding areas (e.g., Ammonia beccarii forma beccarii from the river). Opportunistic species (e.g., Bulimina marginata, Cassidulina carinata) characterised by high reproductive rates have much higher relative abundances in the dead than in the living fauna. Cluster analyses based on dead foraminiferal assemblages divide our study area into four main thanatofacies directly related to distinct local environmental conditions prevailing in the prodelta. Close to the river mouth, Ammonia beccarii forma beccarii and Ammonia tepida are found in sediments subject to a high riverine influence (i.e., bottom currents, high organic and inorganic material input of continental origin). Elphidium species are abundant in the silty-sandy relict deltaic lobe west of the river mouth which is characterised by strong longshore currents that disturb the benthic environment. Nonion fabum, Rectuvigerina phlegeri and Valvulineria bradyana are found along the coast west of the Rhône River mouth, in the area defined as the "river plume" thanatofacies. In the more stable and deeper prodeltaic area, species known to feed on fresh phytodetritus (e.g., Bulimina aculeata/marginata, C. carinata, Hyalinea balthica) dominate the faunas. Since only minor variations in species relative abundances and
\end{abstract}


spatial distributional patterns are observed between the living and the dead faunas, we consider that our thanatofacies have not been influenced by substantial transport of dead tests. This suggests that fossil benthic foraminifera can provide a reliable tool for investigating the development of the palaeo-Rhône prodelta.

\section{Highlights}

Dead faunas were compared with living ones at 41 stations in the Rhône prodelta. Minor compositional and spatial variations exist between living and dead faunas. Four thanatofacies reflect distinct local environmental conditions in the prodelta. Fossil benthic foraminifera are reliable tools to study the paleo-Rhône prodelta.

Keywords : Benthic foraminifera, Rhône prodelta, Taphonomy, Thanatofacies, Palaeoceanography 


\section{Introduction}

Because of their widespread distribution in various environmental settings (i.e., mud flats, shallow coastal areas, continental slope, deep-sea...) and their adaptability to various ecological conditions (i.e., substrate, oxygen and food availability), benthic foraminifera are very useful tools for environmental studies in modern habitats. The preservation in sediments of their calcareous and in some cases agglutinated tests after death makes them also a perfect proxy for palaeoenvironmental reconstructions (Gooday, 2003; Murray, 2006; Jorissen et al., 2007). However, the use of foraminiferal faunas in palaeoenvironmental studies requires a good knowledge of recent foraminiferal faunas (e.g., species composition, abundances), and of the bias which is introduced when these recent faunas are preserved in the sediment record. Indeed, important differences in faunal composition may be observed between living and dead faunas at the same site (Murray, 1991; Jorissen and Wittling, 1999). Therefore, the identification of these differences and the taphonomical and biological processes responsible for them is a key step in the investigation and interpretion of fossil benthic foraminiferal records. Transport of small-sized specimens by bottom currents, and dissolution or destruction of the most fragile species (e.g., some agglutinated species) may change the composition of dead faunas compared with the living ones (Murray, 1991; de Stigter et al., 1999; Jorissen and Wittling, 1999; Fontanier et al., 2008a). Moreover, some biological factors linked to population dynamics, such as interspecific differences in reproduction rates or seasonal variability in standing stocks, may result in considerable differences between the living fauna present at any one time and the fossil fauna preserved at the same site (de Stigter et al., 1999; Jorissen and Wittling, 1999). In fact, in environments subjected to important seasonal and/or interranual variations in organic matter fluxes and sediment/bottom water oxygenation (e.g., continental shelves), dead foraminiferal faunas reflect a time-averaged mixture of the assemblages succeeding each other in time, and provide an integrated picture 
of the population dynamics and of the functioning of the ecosystem as a whole (Murray, 1991; Jorissen and Wittling, 1999).

The Rhône River delta is a complex hydrological system located in the Gulf of Lions (NW Mediterranean). Previous ecological studies on benthic foraminifera from this area have concentrated on the spatial distribution of living faunas in relation to the Rhône prodeltaic environment (Kruit, 1955; Blanc-Vernet, 1969; Bizon and Bizon, 1984a; Mojtahid et al., 2009; Goineau et al., 2011, 2012). Studies by Mojtahid et al. (2009) and Goineau et al. (2011) both concluded that living foraminiferal faunal composition and spatial distribution in the prodelta are controlled not only by the quality (fresh or degraded), quantity and origin (continental or marine) of sedimentary organic matter but also by hydro-sedimentary processes and sediment grain size. Another major constrain is the intensity of aerobic (i.e., sediment oxygen penetration depth) and anaerobic degradation of the organic matter (nitrate/nitrite consumption), which directly depends on the quality and quantity of the organic material. These parameters may vary over the year according to the Rhône River discharge and the intensity of riverine and marine primary production. The wide range of environmental conditions that succeed each other during the course of the year in the Rhône prodelta is responsible for rapid changes in faunal characteristics, even at a single site (Goineau et al., 2012).

The aim of the present study is to investigate the present-day spatial distribution of dead foraminiferal faunas in order to develop a reliable proxy for future environmental reconstructions over the Holocene in the Rhône prodelta. To achieve this objective, we first characterise dead foraminiferal faunas sampled at 41 stations in the Rhône prodelta by describing the faunal diversity, composition, and by defining thanatofacies. Then, in order to explore potential taphonomical and biological processes, we identify differences between 
these dead faunas and the living ones described by Mojtahid et al. $(2009,2010)$ and Goineau et al. (2011) by comparing their composition and spatial distribution in the prodelta.

\section{Material and Methods}

\subsection{Study area}

The Rhône River flows from the mountain chains of the Alps to the Gulf of Lions (Mediterranean Sea), and drains a catchment area of $97800 \mathrm{~km}^{2}$. It is characterised by heterogeneous substrates (calcareous and crystalline rocks from the Jura, Alps and Massif Central mountains) and three different climatic zones (alpine, oceanic and Mediterranean), resulting in strong seasonal and interannual variability of water discharge and terrigeneous input to the deltaic system. With an annual mean flow of $1700 \mathrm{~m}^{3} \cdot \mathrm{s}^{-1}$ (Pont et al., 2002), the Rhône River is the main source of freshwater, organic-inorganic material and nutrients in the Gulf of Lions (Lochet and Leveau, 1990; Durrieu de Madron et al., 2000, 2003). The mixing between riverine (low salinity) and marine (high salinity) waters generates a typical microtidal saltwedge in the Rhône channel. The landward extension of this wedge is mainly controlled by the river discharge. During high-water discharge $\left(>3000 \mathrm{~m}^{3} . \mathrm{s}^{-1}\right)$, the salt wedge is pushed seaward to the river mouth. Beyond the river mouth, the freshwater forms a plume that flows on the surface of marine waters. This surficial layer of freshwater has no impact on bottom-water salinity, even in the immediate vicinity of the river mouth (Eisma, 1993). The offshore extension and shape of this turbid river plume depend on the Rhône outflow (low/high discharge), wind regime (Mistral and Tramontane; Naudin et al., 1997; Millot, 1999) and the intensity of the North Mediterranean Current (Béthoux and Prieur, 1983; Millot, 1990). Although 30\% of the introduced particles are transferred to the slope and to the deeper basin (Got and Aloisi, 1990), a major part of the riverine terrigeneous input is deposited close to the river outlet, from 0 to $60 \mathrm{~m}$ water depth and from 0 to $6 \mathrm{~km}$ off the 
mouth, thus forming a delta front and a prodeltaic area (Rabineau et al., 2005). This zone is subject to very high deposition rates ranging from 30 to $50 \mathrm{~cm}$.year ${ }^{-1}$ (Calmet and Fernandez, 1990; Radakovitch et al., 1999; Miralles et al., 2005). Because of these important riverine supplies, the Gulf of Lions is one of the most productive areas of the Mediterranean Sea (Diaz, 2000). Phytoplankton primary production is maximal from March to May with Chl- $a$

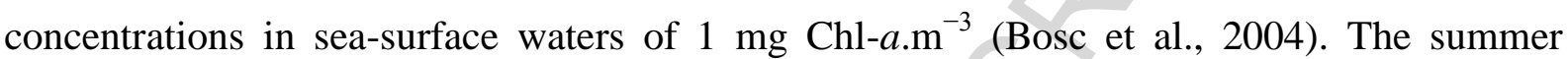

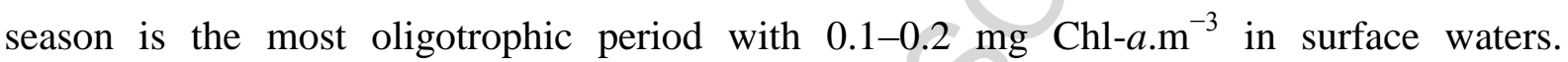
Conditions in the Rhône prodelta remain fairly eutrophic over the year. However, an "oligotrophic" (i.e., less eutrophic) period occurs in late summer-early fall (i.e., from August

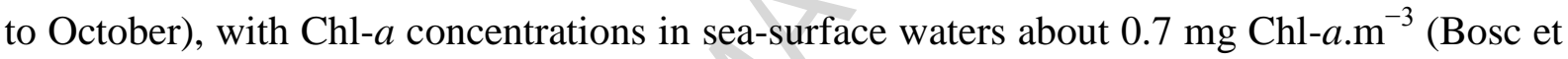
al., 2004). In the Rhône River, riverine phytoplankton blooms also occur during spring. This riverine production can be exported to the open sea in the surface waters of the river plume (Harmelin-Vivien et al., 2008).

The Rhône River has existed since the Messinian crisis (between -5.96 and -5.33 Ma), when the Mediterranean sea-level fell by about $1500 \mathrm{~m}$ (Clauzon, 1974). During the Holocene, both sea-level variations and enhanced human activities modulated sedimentary fluxes and erosional processes that control the morphology of the deltaic and prodeltaic systems (Berendsen and Stouthamer, 2000; Stouthamer, 2001). Since 4000 yr BP (Before Present), the Rhône River has developed several successive arms and mouths such as the Grand Passon $\left(13^{\text {th }}\right.$ century-1607 AD), the Bras de Fer (1585-1711 AD), the Piémanson (1711-1856 AD), the Pégoulier (1711-1892 yr BP) and the Roustan channels (1711 ADToday) (Colomb et al., 1975; Rossiaud, 1994; Vella et al., 2005). Their relict structures, which are still visible in the modern deltaic plain and on the continental shelf (Vella et al., 2005) (Fig. 1), are eroded and redistributed alongshore according to wave action (Sabatier and Suanez, 2003). For the last 200 years (i.e., since the $18^{\text {th }}$ century), engineering works (bank 
revetment, groynes, hydraulic deflectors, dams) have stopped this natural evolution, leading to the fixation of the present Roustan mouth and channel (Sabatier et al., 2006).

\subsection{Dead foraminiferal faunal sampling and analyses}

Forty-one stations were sampled from the $R / V$ Téthys II (INSU) in June 2005 and September 2006 during the MINERCOT 2 and the BEHEMOTH cruises, respectively. Sediment cores of $72 \mathrm{~cm}^{2}$ surface area were collected using a Barnett multicorer (Barnett et al., 1984) at water depths ranging between 15 and $100 \mathrm{~m}$ (Fig. 1, Table 1). At each station, one core was sliced on board for benthic foraminiferal analyses into $0.5 \mathrm{~cm}$ levels from the surface down to $2 \mathrm{~cm}$ depth. Deeper layers were sliced into $1 \mathrm{~cm}$ levels down to $5 \mathrm{~cm}$ depth, except at stations M2, M5, M6, M8, M10, M12, M16, M18, M20, M23, M24 (MINERCOT 2 cruise) where $3 \mathrm{~cm}$-thick slices were sampled (i.e., 2-5 sediment layer). Each sediment layer was then preserved in $95 \%$ ethanol with 1 g. $1^{-1}$ Rose Bengal. Sediment samples were sieved in the laboratory using sieves of 63 and $150 \mu \mathrm{m}$ mesh size. All living (Rose Bengal stained) specimens from the $>150 \mu \mathrm{m}$ size fraction were hand-picked in water from the surface down to $5 \mathrm{~cm}$ depth. All detailed methodology, results and observations relating to these living faunas are described by Mojtahid et al. (2009) and Goineau et al. (2011). For the present study, we analysed dead (unstained) foraminifera in the $150-\mu \mathrm{m}$ size fraction of the $3-4 \mathrm{~cm}$ or 2-5 cm sediment layers. As both sediment intervals are likely located in the surface mixed layer (Zuo et al., 1997; Miralles et al., 2005), non-fossilising species can make a nonnegligible contribution to the dead faunas preserved within them. Therefore, we consider these faunas to be "sub-fossil". Deep infaunal species, which may be under-represented in surface levels (Loubere, 1989), can also be well represented. Samples were dried at $50^{\circ} \mathrm{C}$ in an oven. Those with very high benthic foraminiferal abundances were split with an Otto Microsplitter. Foraminifera from complete samples or splits were hand-sorted until a 
minimum of 300 individuals was counted. Since taphonomic processes induce an important loss of foraminifera, especially the organically-cemented agglutinated species (Bizon and Bizon, 1984b; Schröder, 1988; Bender, 1995), we considered only potentially fossilising species, i.e., calcareous perforates, miliolids and agglutinates with a calcitic cement, in the following analyses. We have also combined dead foraminiferal faunal databases for June 2005 and September 2006 to obtain a detailed geographical overview of dead fossilising faunas in the prodeltaic area. We did not include two stations (M1 and BT41) because of their very low number of fossilising individuals ( $<10$ specimens). For the 39 other stations, total abundances for the fossilising part of the foraminiferal assemblage (D) were normalised to a $100 \mathrm{~cm}^{3}$ sediment volume, and Shannon $(\mathrm{H})$ and Evenness (E) indices were calculated according to

$H=-\sum_{i} \frac{n_{i}}{n} \ln \frac{n_{i}}{n}$

where " $n$ " is the number of individuals of species " $i$ ", and " $n$ " is the total number of individuals in the sample.

$E=e^{H} / S$

where" $e$ " is a constant having a value of 2.7, " $H$ " is the value of the Shannon-Wiener index, and" $S$ " is the number of species.

For each core, we calculated the relative contribution (\%) of each species to the dead fossilising fauna (i.e., total number of dead fossilising specimens). Cluster analyses based on the relative abundances of major species ( $\geq 5 \%$ ) were applied to the 39 stations (Q-mode) and the 23 major fossilising species (R-mode). Using the data analysis software system STATISTICA (StatSoft, Inc., version 8), we constructed tree diagrams using the unweighted pair-group (average) method based on the Pearson correlation coefficients.

In order to evaluate differences between living and dead faunas, we first calculated the Bray-Curtis dissimilarity $(\mathrm{BC})$ at each station. This index, which is based on the relative 
abundances of the major species, describes the dissimilarity in species composition by pairwise comparison of the live and the dead assemblage (Bray and Curtis, 1957). Values range from 0 (no dissimilarity, i.e., samples totally similar) to 1 (samples totally dissimilar). We then calculated the $\mathrm{L} /(\mathrm{L}+\mathrm{D})$ ratio (\%Living/(\%Living+\%Dead); Jorissen and Wittling, 1999) for all species $\geq 5 \%$ in either living fossilising or dead assemblages from the June 2005 (MINERCOT 2 cruise) and September 2006 (BEHEMOTH cruise) databases. We first calculated corrected relative abundances for all species in the living assemblages after substracting all non-fossilising agglutinated species. Next, we compared these corrected percentages with percentages based on the dead faunas, again considering fossilising species only. $\mathrm{L} /(\mathrm{L}+\mathrm{D})$ ratios between 0 and 0.5 indicate that a species is relatively more abundant in the dead than in the living assemblage, whereas a value $>0.5$ indicate that a species is more abundant in the living fauna. For each major species, we also calculated the Pearson correlation coefficient which reflects the relationship between its relative abundance in the dead and the living faunas (June 2005 and September 2006, separately) at the 39 stations. This metric indicates whether the spatial distribution of each major species in the Rhône prodelta is significantly similar in the living and the dead faunas (level of similarity: $\mathrm{p}<$ $0.05)$.

\section{Results}

\subsection{Density, diversity and equitability of dead fossilising foraminiferal faunas}

A total of 88 fossilising species (63 calcareous perforates, 22 miliolids and 3 fossilising agglutinates) plus 16 non-fossilising agglutinated species were identified in the dead faunas from either the 3-4 $\mathrm{cm}$ or the 2-5 $\mathrm{cm}$ levels (Appendices C and D). Nonfossilising agglutinated species (i.e., agglutinates with an organic cement) make up to $30 \%$ of the dead assemblages at some stations. Four non-fossilising agglutinated species represent 
more than $5 \%$ of the dead assemblage in at least one core: Clavulina cylindrica, Cribrostomoides wiesneri, Eggerella scabra and Lagenammina difflugiformis. However, as explained in section 2.2., we removed all non-fossilising agglutinated species and recalculated percentages using only fossilising species (i.e., calcareous perforates, miliolids and fossilising agglutinates). The abundances of fossilising species (D) are lowest (D $<1000$ ind./100 $\mathrm{cm}^{3}$ ) between 0 and $\sim 10 \mathrm{~km}$ from the river mouth and along the western coast (Fig. 2a). Species richness $(\mathrm{S})$ and the Shannon index $(\mathrm{H})$ show a similar spatial pattern, with lowest values $(\mathrm{S}<$ $30, \mathrm{H}<2.5)$ in a $\sim 10 \mathrm{~km}$ wide area around the river mouth. Two corridors of relatively low biodiversity extend from the river mouth towards the south-west and along the western coast, in an east-west direction (Fig. 2b,c). Species richness ranges from 6 (Station BT28, $18 \mathrm{~m}$ ) to 52 (Station BT48, $100 \mathrm{~m}$ ), whereas the Shannon index $(\mathrm{H})$ varies between 1.19 (Station BT 28, $18 \mathrm{~m}$ ) and 3.06 (Station BT48, $100 \mathrm{~m}$ ). The Evenness index (E) has an irregular spatial distribution. High values are recorded close to the river mouth (0.89 at Station M9) and at deeper Stations M19, M20 and M24 (from 0.52 to 0.60), whereas minimal values (from 0.30 to 0.39 ) are observed at intermediate stations (e.g., BT23, BT18, M15) located between 4.4 and $8.9 \mathrm{~km}$ from the mouth (Fig. 2d).

\subsection{Cluster analyses}

Twenty-three species contribute $\geq 5 \%$ to the dead fossilising fauna in at least one core (Appendix B). The two-way cluster analysis based on the percentage contributions to the dead fossilising fauna of these 23 fossilising major species divides the 39 stations into 4 groups (Qmode clustering), and underlines the presence of 4 groups of species (R-mode clustering) (Fig. 3). The cumulative percentage of each group of species was calculated for each station, and their spatial distribution mapped using the surface mapping software Surfer (Golden Software, version 7.04) (Fig. 4). A 200-m spaced grid node created by a krigging interpolation 
method produced spatial maps from irregularly spaced data. Blanking boundaries were defined on the basis of station locations. Q-mode Cluster A groups Stations BT28 and BT35, located in the immediate vicinity of the Rhône River mouth (18-20 m water depth, 1-3.1 km from the mouth. R-mode Cluster 1, which is composed of Ammonia beccarii forma beccarii and Ammonia tepida, exhibits maximal abundances at these stations (78.8\% and $37.3 \%$, respectively). Q-mode Cluster B corresponds to Stations BT11 and BT20 along the coast west of the river mouth (15-26 m water depth, $\sim 8-14 \mathrm{~km}$ from the mouth). At these stations, high relative contributions of Elphidium advenum, Elphidium crispum, Bulimina elongata, Elphidium granosum, Elphidium poeyanum and Quinqueloculina lata, are recorded (53.2\% at Stations BT11 and 50.4\% at station BT20). These species correspond to R-mode Cluster 2. Stations M2, M3, M4, M5, M6, BT1, BT9, BT18, BT26, BT33 and BT39 (37-69 m water depth, 2.8-22.2 $\mathrm{km}$ from the mouth) constitute Q-mode Cluster C extending from the prodeltaic area ( $<60 \mathrm{~m}$ water depth) to a narrow $\mathrm{W}-\mathrm{SW}$ corridor along the northern border of the Rhône River plume (Fig. 1). High relative abundances of the isolated species Nonionella turgida (30.0 to $50.8 \%$ of the fossilising fauna) and of R-mode Cluster 3 species, composed of Rectuvigerina phlegeri, Nonion fabum, and Valvulineria bradyana, are found at Q-mode Cluster C stations. The remaining 23 stations constitute Q-mode Cluster D, which extends from the southern border of the prodeltaic area to the outer shelf (58-100 m water depth, 4.422.4 $\mathrm{km}$ from the mouth). The northern border of this area is characterised by high percentages of the isolated species Cassidulina carinata (Stations BT23, M7, M8, M10, M15, M18) and, to a less extent, Pyrgo oblonga (Stations M7 and M8). Deeper sites (> 60 m water depth) are dominated by R-mode Cluster 4 species, namely Ammonia beccarii forma inflata, Pseudoeponides falsobeccarii, Textularia agglutinans, Quinqueloculina seminula, Bigenerina nodosaria, Melonis barleeanus, Bulimina aculeata, Hyalinea balthica, and Bulimina marginata. 


\subsection{Living-dead comparison}

\subsubsection{Bray-Curtis dissimilarity}

Bray-Curtis (BC) dissimilarity values range from 0.23 to 0.70 (Table 2). The highest values $(\mathrm{BC} \geq 0.60)$ are obtained at stations M7, M13, BT11, BT20 and BT23, and the lowest values $(\mathrm{BC} \leq 0.30)$ at stations M20, BT26 and BT30. No clear trend in the spatial distribution of the values is highlighted.

\subsection{2. $\mathrm{L} /(\mathrm{L}+\mathrm{D})$ ratios}

In June 2005 and September 2006, a total of 26 species have a relative abundance $\geq 5 \%$ in the fossilising living and/or dead faunas (Tables 5 and 6). Quinqueloculina tenuicollis and Triloculina trigonula are observed only in the live and/or dead assemblages sampled in September 2006. During this period, T. trigonula is relatively more abundant in the living fauna, while $Q$. tenuicollis is may even be entirely represented by live specimens. Ammonia tepida shows higher relative abundances in the dead fauna, whereas more heterogeneous living/dead ratios are recorded for $A$. beccarii forma beccarri. Dead individuals of $A$. beccarii forma beccarri are relatively more abundant at stations close to the river mouth (Stations BT20, BT24, BT26, BT33, BT39). An opposite trend is recorded at stations along the western coast (Stations BT11, BT15, BT18, BT23, BT35) where A. beccarii forma beccarii is relatively more abundant in the living fauna. In samples from June 2005, a distinction between A. tepida and A. beccarii forma beccarii was made in the dead assemblage (this study) but not in the living assemblage (Mojtahid et al., 2009). During this sampling period, Ammonia spp. (grouping A. beccarii forma beccarii and A. tepida), follows the same trend as A. beccarii forma beccarri in September 2006 (Table 5).

Bulimina marginata, Elphidium spp. (i.e., E. advenum, E. crispum, E. granosum, E. poeyanum), H. balthica and $P$. oblonga are relatively more abundant in the dead fauna of both 
sampling periods, whereas Bolivina alata and Nonion fabum exhibit a totally opposite trend, with higher relative abundances in the living faunas of both sampling periods.

Quinqueloculina seminula and $P$. falsobeccarii show similar to higher relative abundances in the dead than in the living faunas. Some exceptions are recorded at Station BT37, M10, M16 and BT22 where living specimens have higher relative abundances. On the contrary, Rectuvigerina phlegeri is more abundant in the living fauna, except at Stations BT33 and M9 where this species is better represented in the dead fauna.

Nonionella turgida and $V$. bradyana tend to be either equally or more abundant in the dead than in the living fauna from the river mouth to the south-western part of the prodelta. However, at the eastern and southern stations, living individuals of N. turgida (Stations BT1, BT23, ВT29, ВT36, ВT37) and V. bradyana (BT22, ВT30, ВT36, ВT39, M16, M23 and M24) predominate.

Different trends in living/dead ratios are evident in the case of $B$. nodosaria, $B$. aculeata and C. carinata in June 2005 and September 2006. Bigenerina nodosaria is better represented in the dead assemblage of June 2005, whereas living individuals are relatively more abundant in September 2006. In June 2005, living specimens of B. aculeata and $C$. carinata make a much higher relative contribution, especially at stations located in the southern to the south-eastern prodeltaic area (e.g., Stations M9, M10, M19, M20, M23, M24). Conversely, C. carinata and B. aculeata are relatively more abundant in the dead fauna in September 2006.

Values of $\mathrm{L} /(\mathrm{L}+\mathrm{D})$ are more variable in the case of the 6 remaining species $(A$. beccarii forma inflata, B. elongata, M. barleeanus, Q. lata and T. agglutinans). These exhibit a higher relative abundance in the dead fauna or in the living fauna, without any clear spatial trend (i.e., heterogeneous spatial distribution of living/dead ratios in the prodelta) and/or temporal continuity (i.e., different trends between June 2005 and September 2006 faunas). 


\subsubsection{Pearson correlation coefficients}

Pearson correlation coefficients, which compares the spatial distribution of the living and dead fossilising faunas for each major species and group of species defined by R-mode clustering, reveals significant positive correlations for the four groups of species $(r>0.68, p<$ 0.05; Table 7). These significant positive correlations confirm the similar spatial distribution patterns of these groups of species in the living and the dead faunas of June 2005 and September 2006. When considering each species separately, the correlation coefficients for 15 of the 23 species are $>0.51$. The 8 remaining species ( $R$. phlegeri, V. bradyana, A. beccarii forma inflata, B. marginata, $Q$. seminula, $C$. carinata and $P$. oblonga) have values ranging between 0.06 and $0.46(\mathrm{p}<0.05$; Table 7). Rectuvigerina phlegeri is observed closer to the coast in the dead (Station BT33, M6, M13; 40-75 m water depth) than in the living fauna (Stations BT30 and M12; >13 km from the mouth; Tables 3 and 4). Maximal abundances of V. bradyana in the dead assemblage are recorded at Stations BT18, M6 and M14 ( 7.5-8.6 $\mathrm{km}$ from the mouth; Tables 3 and 4), whereas live specimens are more abundant in the southern to south-eastern part of the study area (Stations M6, M16, M24, BT22, BT36, BT37; $>8.6 \mathrm{~km}$ from the river mouth). In Cluster 4, living specimens of A. beccarii forma inflata, $B$. marginata and $Q$. seminula are restricted to the south-eastern part of the study area, whereas dead specimens are observed as far as Stations BT1 and M12 along the western coast ( 13 to $22.2 \mathrm{~km}$ from the mouth; Tables 3 and 4). In the dead faunas, percentages of $C$. carinata are highest at stations located on the northern border of the outer shelf area, from Stations M15, BT23, M8, M7 to Station M22 (Fig. 4g, Tables 3 and 4). However, living specimens of $C$. carinata occur more sporadically across the Rhône prodelta, with patches of maximal abundances at Stations BT39, BT29, M19, M22 located between 4.1 and $18 \mathrm{~km}$ from the mouth (Fig. 4g, Tables 3 and 4). 


\section{Discussion}

\subsection{Living-dead comparison}

We compared dead and living foraminiferal assemblages from the Rhône prodelta, a highly dynamic environment characterised by very high rates of sediment accumulation

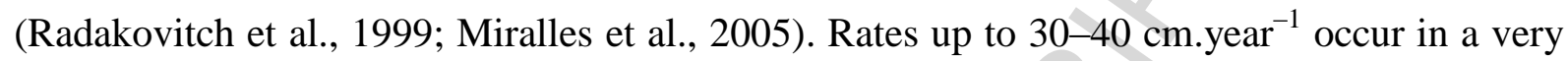
restricted area, in the immediate vicinity of the river mouth. On the delta front (20 to $\sim 60 \mathrm{~m}$ water depth), the accumulation rate "drops" to $\sim 17-18 \mathrm{~cm}$.year ${ }^{-1}$. In the remaining parts of the prodelta, accumulation rates are very much lower, ranging from 0.25 to $0.65 \mathrm{~cm}$.year ${ }^{-1}$ (Zuo et al., 1991; Radakovitch et al., 1999; Miralles et al., 2005). Such variations can have a major impact on the nature and intensity of the taphonomical processes that shape dead faunas. It seems likely that older faunas (those from areas with low sedimentation rates) are more severely affected by degradation processes than younger faunas (those from areas with high sedimentation rates). The Bray-Curtis (BC) dissimilarity index calculated at each station is sometimes fairly high, indicating significant differences between live and dead assemblages (Table 2). These differences are not surprising in shallow coastal environments, as reported in previous studies (e.g., Murray, 1991; Jorissen and Wittling, 1999; Murray and Alve, 1999; Diz and Francés, 2009). However, no clear trend is evident in the spatial distribution of BC dissimilarity values. Important dissimilarities between the dead and the living faunas are recorded at stations located in the delta front, where sedimentation rates are high, as well as at stations located in the deepest southeastern part of our study area, where sedimentation rates are "low". Therefore, the intensity of the taphonomical processes that influence our faunas does not seem to be biased by heterogeneous sediment accumulation rates occurring in the Rhône prodelta.

The comparison of living and dead foraminiferal faunas sampled during two contrasting time periods (June 2005, high primary production; September 2006, low discharge 
and low primary production) reveals three groups of species: (1) those relatively more abundant in the living than in the dead fauna; (2) those relatively more abundant in the dead fauna; (3) those for which no clear pattern is evident. In the case of some species, the pattern even changed depending on the sampling period. These three patterns may reflect three possible factors: (1) transport processes leading to an export or inport of autochthonous/allochthonous individuals; (2) seasonal variability in the reproduction and growth rate of living individuals; and/or (3) post-mortem physico-chemical destruction of the test (i.e., fossilisation rate). We consider these potential influences in the following sections.

\subsubsection{Transport processes}

\section{Shallow-water habitats}

Hydrodynamic processes are important at the shallowest stations located along the coast west of the river mouth. This coast is an erosional area where wave-generated longshore currents laterally redistribute the sediments (Fig. 1; Sabatier and Suanez, 2003), leading to sediment outcrops of the relict deltaic lobe of Bras de Fer (Blanc, 1977; L'Homer, 1993; Sabatier et al., 2006). When this deltaic lobe was active (i.e., 1585-1711 AD; Colomb et al., 1975; Vella et al., 2005), foraminiferal faunas inhabiting this area were dominated by Elphidium species (A.-S. Fanget, unpublished data). Therefore, higher relative abundances of Elphidium species observed in the dead faunas from this area (e.g., Stations M2, BT1, BT11, BT20, BT35) may be related to a mixing of relict fossil assemblages with modern dead faunas. Large numbers of these fossil species would lower the relative abundances of autochthonous species in the modern dead faunas, possibly explaining high living/dead ratios of Bulimina elongata, Quinqueloculina lata and Triloculina trigonula at these stations.

Transport processes may also bring allochthonous live and/or dead foraminifera to our study area. For example, Ammonia beccarii forma beccarii is adapted to a wide range of 
environmental conditions. Within the Rhône deltaic system, living and dead specimens have been reported from the interdistributaries (i.e., inner shore environments) to shallow coastal areas (0 to $\sim 60 \mathrm{~m}$ water depth) (Kruit, 1955; Blanc-Vernet, 1969; Goineau et al., 2011). Therefore, input of material from these environments, either during Rhône flood events or under the action of wind-driven longshore currents combined with waves during major storm events (from the E-SE; Dufois et al., 2008), could explain the relatively higher abundances of dead specimens of $A$. beccarii forma beccarii recorded in the vicinity of the Rhône River mouth.

\section{Shelf habitats}

At deeper sites in the Rhône prodelta, there is a westward to northwestward shift in the spatial distribution of Rectuvigerina phlegeri, Valvulineria bradyana, Ammonia beccarii forma inflata, Bulimina marginata and Quinqueloculina seminula in the dead assemblage (Tables 3, 4 and 7; Fig. 4). In the living faunas of June 2005 and September 2006, N. fabum, R. phlegeri and V. bradyana (R-mode Cluster 3) are distributed into a south-western direction. This distribution coincides with the yearly mean position of the river plume suggested by Naudin et al. (1997). There are two possible explanations for the distribution of these species closer to the coast in the dead fauna. The first is that the Rhône River plume spreads along the coast in an E-W direction during most of the year. Since the marine extension and shape of the Rhône River plume depend on Rhône River outflow, wind regime and the strength of the North Mediterranean Current (Naudin et al., 1997), it is likely to extend far offshore along a south-western corridor only occasionally. However, this seems inconsistent with the southwestern yearly mean position described by Naudin et al. (1997). The second possible explanation involves a westward transport of dead foraminifera. The Rhône prodelta is under the influence of south-east to south-west swells (Fig. 1), which are effective in remobilising 
sediment from the inner continental shelf, especially during storm events (Brunel, 2010). These storms, especially those associated with winds from the E-SE, also generate important wind-driven circulation, capable of transporting sediment in an alongshore direction across the entire inner continental shelf (Dufois et al., 2008). Mojtahid et al. (2010) showed that $R$. phlegeri and $V$. bradyana thrive in shallower sediment microhabitats than N. turgida and $N$. fabum at stations located under the river plume and are therefore particularly susceptible to sedimentary transport induced by storm swells. Individuals of species such as $R$. phlegeri and $V$. bradyana are therefore likely to be transported from the east (living assemblages) to the west (dead faunas) along isobaths. Dead individuals of A. beccarii forma inflata, B. marginata and Q. seminula (grouped into R-mode Cluster 4) could also be transported westward by south-eastern swells. However, the influence of storm swells may be reduced in the case of these species, which are mainly distributed in the deepest part of the study area (> $60 \mathrm{~m}$ water depth). An alternative explanation is that $A$. beccarii forma inflata, $B$. marginata and $Q$. seminula are able to thrive (and to fossilise) in sediments located far to the west during periods of minimal extension of the Rhône River plume.

\subsubsection{Biological processes}

Biological processes depend on the ecology of the species concerned, and particularly on differences in population dynamics between species. Reproduction rate may also vary both in time and space for one particular species.

Seasonal variability in the reproduction rate of Ammonia tepida, Bigenerina nodosaria, Bulimina aculeata, Bulimina marginata, Cassidulina carinata, Hyalinea balthica, Nonionella turgida and Valvulineria bradyana has been well documented in many ecological studies. In particular, B. aculeata, B. marginata, C. carinata, H. balthica, N. turgida and V. bradyana are reported to be opportunistic species able to respond to fresh organic 
phytodetritus input with increased reproduction (e.g., Jorissen et al., 1992; De Rijk et al., 2000; Donnici and Serandrei Barbero, 2002; Fontanier et al., 2003; Kitazato et al., 2003; Nomaki et al., 2005a, 2005b, 2006; Eberwein and Mackensen, 2006; Langezaal et al., 2006; Diz and Francés, 2008; Duchemin et al., 2008). In the Rhône prodelta, Goineau et al. (2011) reported higher relative contributions of $B$. aculeata, $C$. carinata and $V$. bradyana in the living fauna at the end of the spring bloom (June 2005) than during periods of the year when conditions were more oligotrophic (September 2006). The opportunistic response of $C$. carinata to fresh phytodetritus inputs could lead to heterogeneous, patchy growth of this species both in space and time, explaining the significantly different spatial distribution patterns of the living and the dead populations (Table 7, Fig.4g). Similarly, a temporal study performed by Goineau et al. (2012) at a shallow station (20 m water depth) in the vicinity of the Rhône River mouth revealed important temporal changes in the absolute and relative abundances of living A. tepida, with a hundred times more individuals per $100 \mathrm{~cm}^{2}$ under high riverine influence (i.e., post-Rhône Rive flood, $~ 94 \%$ of total living fauna) than during periods of low riverine discharge $(<0.5 \%$ of total living fauna).

In the present study, B. aculeata was relatively more abundant in the living than in the dead fauna in June 2005, but better represented in the dead fauna in September 2006. This observation suggests that a high production rate of living B. aculeata in the Rhône prodelta is triggered by eutrophic conditions (e.g., June 2005) and is not associated with periods of low primary production (e.g., September 2006). Bigenerina nodosaria exhibits an opposite temporal pattern, being more abundant in the living than in the dead fauna in September 2006. This is consistent with previous reports of this species in meso-eutrophic environments with moderate to high organic matter fluxes (Schmiedl et al., 2000; Fontanier et al., 2008b). In the case of A. tepida, B. marginata, C. carinata, H. balthica and V. bradyana, dead specimens are relatively more abundant than living ones during both sampling periods, suggesting that these 
species mainly, reproduce at other times of the year. Our results, together with previous studies performed in similar environments, suggest that B. marginata, C. carinata, H. balthica and $V$. bradyana may reproduce at the beginning of the spring bloom. On the other hand, since A. tepida is characteristic of high riverine influence (Goineau et al., 2012), an increased reproduction rate may occur in autumn or early spring during the Rhône flood seasons. Similarly, Goineau et al. (2012) reported stronger production rates of living $N$. turgida during May 2008 at a station located in the prodeltaic area $(68 \mathrm{~m}$ water depth, $4.5 \mathrm{~km}$ from the mouth). The present study revealed a higher contribution of living compared to dead individuals not only during the eutrophic period (June 2005) but also under more oligotrophic conditions (September 2006). This observation can be explained in two different ways. Tests may be lost from the the dead record as a result either of their fragility and/or the likely high deposition rates prevailing in some parts of the Rhône prodelta. Alternatively, N. turgida may be able to feed on less labile organic matter (i.e., degraded and/or continental) in addition to fresh phytodetritus, allowing it to persist and reproduce during the more oligotrophic conditions prevailing in September 2006.

Rapid reproduction by these opportunistic species may have a noticeable influence on the living/dead ratios of other species. Their ability to generate numerous offspring decreases the relative contribution in the dead fauna of species with a lower or a more constant production rate over the year. This mechanism could explain the reduced abundance of Nonion fabum and Rectuvigerina phlegeri in the dead assemblage. Indeed, despite relatively constant percentages in the living fauna under a wide range of environmental conditions (i.e., from productive spring bloom to the more oligotrophic conditions of the late summer; Mojtahid et al., 2009; Goineau et al., 2011, 2012), their relative abundances are halved during the transition from the living to the dead assemblages. The opportunistic species probably 
responsible of this dilution is $V$. bradyana, which is associated with $N$. fabum and $R$. phlegeri within R-mode Cluster 3.

\subsubsection{Test degradation and destruction}

Fossilisation rates of benthic foraminifera depend on the fragility of the test. The dissolution/fragmentation of a test by taphonomic processes leads to a loss of individuals from the living to the dead faunas. In the Rhône prodelta, Quinqueloculina tenuicollis and Bolivina alata, two species that are almost totally absent from the dead faunas, seem to be particularly affected by this phenomenon. Both species possess thin and fragile tests whith chambers that are easily broken, a characteristic that likely leads to their destruction during fossilisation.

\subsection{Foraminiferal thanatofacies}

In the Rhône prodelta, cluster analyses performed on fossilising dead assemblages highlight the presence of four groups of stations (Thanatofacies A-D) and four groups of species (R-mode Clusters 1-4). The spatial distribution of the percentage contributions of these species groups in the living (June 2005 and September 2006) and the dead faunas (Fig. 5) defines four distinct areas in the Rhône prodelta.

Thanatofacies A (Stations BT28 and BT35) is located in the vicinity of the river mouth (Fig. 4a). High abundances of Ammonia tepida and Ammonia beccarii forma beccarii (Rmode Cluster 1) in this area are not surprising as this species association is typical of shallow coastal environments in the vicinity of river mouths (Jorissen, 1987; Donnici and Serandrei Barbero, 2002; Mendes et al., 2004; Rossi and Vaiani, 2008; Frezza and Carboni, 2009). As discussed above (see section 4.1.1.), allochthonous living and/or dead individuals of $A$. beccarii forma beccarii might be transported from the river and/or from shallower 
environments during Rhône River flood periods and/or by the action of longshore currents. In September 2006, living A. beccarii forma beccarii and A. tepida are associated with poorlyoxygenated sediments enriched in organic matter of continental origin (Goineau et al., 2011). In a temporal study conducted in the vicinity of the Rhône River mouth, A. tepida occured under high Rhône discharge conditions and after a major input of riverine sediments (Goineau et al., 2012). Therefore, the presence of A. beccarii forma beccarii and A. tepida in dead assemblages seems to be related to very high riverine influence in the form of organic matter and sediment inputs and bottom currents.

Thanatofacies B corresponds to the coastal area located west of the river mouth (Stations BT11 and BT20) in the relict sandy deltaïc lobe of Bras de Fer (Figs. 1 and 4b). This high-energy environment, affected by strong longshore bottom currents (Sabatier and Suanez, 2003) (Fig. 1), is characterised by a low content of sedimentary organic carbon and labile organic matter (i.e., lipids, amino-acids) of continental origin (Goineau et al., 2011). Bulimina elongata and Elphidium spp. (R-mode Cluster 2) are reported to thrive in shallow marine, silty to sandy substrates under riverine influence (Jorissen, 1988; Barmawidjaja et al., 1992; Bellotti et al., 1994; Frezza and Carboni, 2009).

Thanatofacies $C$ is located between 37 and $69 \mathrm{~m}$ water depth, an area subjected to very high sediment deposition rate in the prodeltaic area (about 15 to $20 \mathrm{~cm}$.year ${ }^{-1}$; Radakovitch et al., 1999; Miralles et al., 2005) (Fig. 4c,e). Important sediment inputs may lead to a dilution of dead faunas, explaining the low abundances and the low diversity observed at these stations (Fig. 2). The association of Nonion fabum, Rectuvigerina phlegeri, Valvulineria bradyana (R-mode Cluster 3) and Nonionella turgida (an isolated species that is not included in R-mode Clusters 1-4) has been reported in sediments close to river mouths with substancial inputs of continental OM (e.g., Po River, Ría de Vigo; Rhône River; Jorissen, 1987; van der Zwaan and Jorissen, 1991; Barmawidjaja et al., 1992; Donnici and Serandrei 
Barbero, 2002; Diz and Francés, 2008; Rossi and Vaiani, 2008; Mojtahid et al., 2009; Goineau et al., 2011). These works describe $N$. turgida as an opportunistic and stress-tolerant species able to live in hypoxic sediments enriched in low-quality OM. In the Rhône prodelta $N$. turgida is also described having an opportunistic behaviour after a phytoplankton blooms (Goineau et al., 2012). Important variations in the production rate of this species over the year may explain why $N$. turgida does not group with $N$. fabum, R. phlegeri and V. bradyana in the cluster analysis of the dead faunas. Nevertheless, the fact that $N$. turgida often occurs together with R-mode Cluster 3 species (N. fabum, R. phlegeri and V. bradyana) in the dead foraminiferal assemblage would be indicative of substancial continental OM inputs in the prodelta. The riverine influence is still significant in terms of sediment inputs, but conditions are less stressfull than close to the river mouth (Thanatofacies A).

Thanatofacies D corresponds to stations located in the southern to south-eastern part of the study area (Fig. 4d). In June 2005 and September 2006, living specimens of Ammonia beccarii forma inflata, Bigenerina nodosaria, Bulimina aculeata, Bulimina marginata, Hyalinea balthica, Melonis barleeanus, Pseudoeponides falsobeccarii, Quinqueloculina seminula and Textularia agglutinans (R-mode Cluster 4) are also observed in this part of the outer shelf (see section 4.1.1.). According to Mojtahid et al. (2009) and Goineau et al. (2011), the continental (i.e., riverine) influence in terms of organic matter and sediment fluxes is significantly lower at those sites than in the other parts of the Rhône prodelta. With less stressed and more stable environmental conditions, foraminiferal diversity increases considerably. The occurrence of the opportunistic phytodetritus feeders $B$. marginata, $B$. aculeata, $H$. balthica and $M$. barleeanus in the dead assemblage indicates that this area is supplied by fresh organic matter inputs of more marine origin (Mojtahid et al., 2009; Goineau et al., 2011), probably during the spring bloom (see section 4.1.2.). 
Percentages of Cassidulina carinata (an isolated species that is not included in Rmode Clusters 1-4) in the dead faunas are maximal at Stations M15, BT23, M8, M7 to Station M22, located on the northern border of the outer shelf area (Thanatofacies D) (Fig. 4g, Tables 3 and 4). This area experiances inputs of organic matter from both riverine and marine sources (Mojtahid et al., 2009; Goineau et al., 2011). Cassidulina carinata can be considered to be characteristic of this mixed influence, responding opportunistically (low Evenness index) to the fresh organic matter inputs that occur during the most eutrophic season (i.e., spring bloom; Mojtahid et al., 2009; Goineau et al., 2011).

Figure 5 shows the cumulative percentages of these different groups of species along a transect perpendicular to the shore that spans Stations BT28, M3, M4, BT26, BT24, BT23 and BT22. Along this transect, we observe a succession of river mouth, river plume, mixed riverine/marine influences, and finally outer shelf faunas. These different influences correspond to the sequence of thanatofacies, and hence the decreasing influence of the Rhône River with increasing distance from the river mouth, as recorded by dead foraminiferal faunas. If observed in the fossil record, a similar succession of foraminiferal faunas would be interpreted to indicate a decrease of the riverine influence over several decades to centuries.

\section{Conclusions}

The study of dead benthic foraminiferal faunas preserved in the Rhône prodelta improves our understanding of the taphonomic processes acting on benthic foraminiferal assemblages in this area. Some species (e.g., Bolivina alata, Quinqueloculina tenuicollis) suffer substancial losses from the living to the dead assemblages, most likely as a result of the fragility of their tests. From the river mouth to the shallow western coast, processes related to riverine inputs and longshore currents may transport dead and/or live specimens of species such as Ammonia beccarii forma beccarii and Elphidium spp. from their area of origin. 
Biological processes may also explain differences observed in the living/dead ratios of some species. Opportunistic species such as Bulimina aculeata, Bulimina marginata, Hyalinea balthica, Nonionella turgida and Valvulineria bradyana, which produce numerous offspring, notably during eutrophic periods, are better represented in the dead fauna sampled outside their main production period. As a result, less opportunistic species, such as Nonion fabum and Rectuvigerina phlegeri, are under-represented in the dead faunas.

Four thanatofacies can be recognised among the time-averaged dead foraminiferal assemblages. The river mouth thanatofacies is characterised by Ammonia beccarii forma beccarii and Ammonia tepida. It constitutes the most strongly Rhône River-influenced part of the whole prodelta. Bulimina elongata, Elphidium spp. and Quinqueloculina lata dominate the dead faunas in sandy-silty sediments to the west of the river mouth, a high-energy shallow environment characterised by strong bottom currents. Nonionella turgida dominates faunas in a zone that experiances strong inputs of river-derived organic matter and sediment. Typical "river plume" faunas occur along the coast west of the Rhône River mouth, although living specimens of these species found in these dead assemblages are more abundant in a southwestern corridor. This contrasting pattern suggests that there is a westward shift of dead tests driven by south-eastern storm swells or wind-driven circulation. Species known to feed on fresh phytodetritus and with a supposedly opportunistic life strategy (e.g., Bigenerina nodosaria, Bulimina aculeatalmarginata, Hyalinea balthica, Textularia agglutinans) characterise the faunas in the more stable and unstressed outer shelf thanatofacies $(60-100 \mathrm{~m}$ water depth). At the confluence of the "river plume" and "outer shelf" thanatofacies, the opportunistic species Cassidulina carinata is associated with organic-matter inputs derived from a mixture of riverine and marine sources. Across all the investigated sites, differences in the relative abundances and spatial patterns of these live and dead foraminiferal assemblages appear to be relatively insignificant. As a result, we consider our thanatofacies to be 
autochthonous rather than allochthonous and therefore representing a sound basis for interpreting the fossil archive. These thanatofacies, characterised by distinct foraminiferal assemblages reflecting different local environmental conditions, provide a valuable tool for investigating the development of the palaeo-Rhône prodelta.

\section{Supplementary data}

\section{Appendix A}

Taxonomic reference list of all major species $(\geq 5 \%)$.

\section{Appendix B}

Spatial distribution of the 23 fossilising major species ( $\geq 5 \%$ in at least one station) belonging to the $>150 \mu \mathrm{m}$ size fraction, based on their percentage contributions to the dead fossilising fauna at each station. Light grey stations correspond to Stations M1 and BT41 excluded from all analyses because of their very low foraminiferal abundances ( $<10$ observed individuals).

\section{Appendix C}

Total dead benthic foraminiferal counts for the June 2005 (levels 3-4 cm or 2-5 cm depth within the sediment; MINERCOT 2) sampling campaign. "D" corresponds to the normalised absolute abundance (No ind./100 $\mathrm{cm}^{3}$ of sediment) for each species at each station; "\%Tot" indicates the relative abundance in the total fauna of each species at each station, whereas "\%Fos" corresponds to the relative abundance of each species in the fossilising fauna (i.e., calcareous perforates, miliolids and fossilising agglutinated species). Grey boxes indicate species with percentages $\geq 5 \%$. 


\section{Appendix D}

Total dead benthic foraminiferal counts for the September 2006 (level 3-4 cm depth within the sediment; BEHEMOTH cruise) sampling campaign. "D" corresponds to the normalised absolute abundance (No ind./100 $\mathrm{cm}^{3}$ of sediment) for each species at each station; "\%Tot" indicates the relative abundance in the total fauna of each species at each station, whereas "\%Fos" corresponds to the relative abundance of each species in the fossilising fauna (i.e., calcareous perforates, miliolids and fossilising agglutinated species). Grey boxes indicate species with percentages $\geq 5 \%$.

\section{Acknowledgements}

We would like to thank the crews and the captain of the $R / V$ Téthys 2 (CNRS-INSU) during the BEHEMOTH-MINERCOT 2 campaigns, and also the invaluable technical assistance of Melissa Gaultier and Olivier Bles from BIAF who helped for laboratory sample treatments and analyses. We acknowledge Grégoire Maillet for the very interesting exchange of ideas, and Andrew J. Gooday for his comments and corrections that helped to enhance the quality of the English language. We are also grateful to two anonymous reviewers for their thorough comments which helped to improve our manuscript. This study was partly financially supported by the ANR VMC - EXTREMA (Vulnérabilité: Milieux et Climats-Episodes météo-climatiques extrêmes et redistribution des masses sédimentaires et des polluants associés au sein d'un système côtier) and by the Regional Council of Pays de la Loire. 


\section{References}

Barmawidjaja, D.M., Jorissen, F.J., Puskaric, S., Van Der Zwaan, G.J., 1992. Microhabitat selection by benthic foraminifera in the northern Adriatic Sea. J. Foraminifer. Res. 22 (4), 297-317.

Barnett, P.R.O., Watson, J., Connely, D., 1984. A multiple corer for taking virtually undisturbed sample from shelf, bathyal and abyssal sediments. Oceanol. Acta 7, 399408.

Bellotti, P., Carboni, M.G., Di Bella, L., Palagi, I., Valeri, P., 1994. Benthic foraminiferal assemblages in the depositional sequence of the Tiber Delta. In: Matteucci, R., Carboni, M.G., Pignatti, J.S. (Eds.), Studies on Ecology and Paleoecology of Benthic Communities. Bollettino della Società Paleontologica Italiana, pp. 29-40.

Bender, H., 1995. Test structure and classification in agglutinated foraminifera. In: Kaminski, M.A., Geroch, S., Gasiński, M.A. (Eds.), Proceedings of the Fourth International Workshop on Agglutinated Foraminifera. The Grzybowski Foundation, Kraków, Poland, pp. 27-70.

Berendsen, H.J.A., Stouthamer, E., 2000. Late Weichselian and Holocene palaeogeography of the Rhine-Meuse delta, The Netherlands. Palaeogeogr. Palaeocl. Palaeoecol. 161 (34), 311-335.

Berné, S., Jouet, G., Bassetti, M.A., Dennielou, B., Taviani, M., 2007. Late Glacial to Preboreal sea-level rise recorded by the Rhône deltaic system (NW Mediterranean). Mar. Geol. 245 (1-4), 65-88.

Béthoux, J.-P., Prieur, L., 1983. Hydrologie et circulation en Méditerranée Nord-Occidentale. Pétrole et techniques 229, 25-34.

Bizon, G., Bizon, J.J., 1984a. Distribution des foraminifères sur le plateau continental au large du Rhône. In: Bizon, J.J., Burollet, P.F. (Eds.), Ecologie des microorganismes en 
Méditerranée occidentale 'ECOMED'. Association Française des Techniciens du Pétrole, Paris, pp. 84-94.

Bizon, G., Bizon, J.J., 1984b. Méthode d'études et mode de prélèvement des sédiments d'ECOMED. In: Bizon, J.J., Burollet, P.F. (Eds.), Ecologie des microorganismes en Méditerranée occidentale 'ECOMED'. Association Française des Techniciens du Pétrole, Paris, pp. 81-83.

Blanc-Vernet, L., 1969. Contribution à l'étude des foraminifères de Méditerranée. Recueil des travaux de la Station Marine d'Endoume Vol. 64, p. 281.

Blanc, J., 1977. Recherche en sédimentologie appliquée au littoral du delta du Rhône, de Fos au Grau du Roi. Publications du Centre National pour l'EXploitation des Océans, p. 69.

Bosc, E., Bricaud, A., Antoine, D., 2004. Seasonal and interannual variability in algal biomass and primary production in the Mediterranean Sea, as derived from 4 years of SeaWifs observations. Global Biogeochem. Cy. 18, 1-17.

Bray, J.R., Curtis, J.T., 1957. An ordination of the upland forest communities of southern Wisconsin. Ecological monographs 27 (4), 325-349.

Brunel, C., 2010. Évolution séculaire de l'avant côte de la Méditerranée Française, impact de l'élévation du niveau de la mer et des tempêtes. PhD Thesis, Université de Provence Aix-Marseille 1, p. 470.

Calmet, D., Fernandez, J.-M., 1990. Caesium distribution in northwest Mediterranean seawater, suspended particles and sediments. Cont. Shelf Res. 10 (9-11), 895-913.

Clauzon, G., 1974. L'hypothèse eustatique et le creusement prépliocène de la vallée du Rhône. Annales de Géographie 456, 129-140.

Colomb, E., Gieu, G., Masse, J.P., Rouire, J., Roux, M., 1975. Notice de la Carte Gélogique 1/50 000, Feuille 1018 d'Istres, p. 47. 
De Rijk, S., Jorissen, F.J., Rohling, E.J., Troelstra, S.R., 2000. Organic flux control on bathymetric zonation of Mediterranean benthic foraminifera. Mar. Micropaleontol. 40 (3), 151-166.

de Stigter, H.C., van der Zwaan, G.J., Langone, L., 1999. Differential rates of benthic foraminiferal test production in surface and subsurface sediment habitats in the southern Adriatic Sea. Palaeogeogr. Palaeocl. Palaeoecol. 149, 67-88.

Diaz, F., 2000. Evolution saisonnière de la production primaire et des processus d'assimilation-régénération de l'azote dans le Golfe du Lion : Estimation d'un bilan de carbone, Approches in situ et modélisation. PhD Thesis, Université d'Aix-Marseille II, p. 351 .

Diz, P., Francés, G., 2008. Distribution of live benthic foraminifera in the Ría de Vigo (NW Spain). Mar. Micropaleontol. 66 (3-4), 165-191.

Diz, P., Francés, G., 2009. Postmortem processes affecting benthic foraminiferal assemblages in the Ría de Vigo, Spain: implications for palaeoenvironmental studies. J. Foraminifer. Res. 39 (3), 166-179.

Donnici, S., Serandrei Barbero, R., 2002. The benthic foraminiferal communities of the northern Adriatic continental shelf. Mar. Micropaleontol. 44 (3-4), 93-123.

Duchemin, G., Jorissen, F.J., Le Loc'h, F., Andrieux-Loyer, F., Hily, C., Thouzeau, G., 2008. Seasonal variability of living benthic foraminifera from the outer continental shelf of the Bay of Biscay. J. Sea Res. 59 (4), 297-319.

Dufois, F., Garreau, P., Le Hir, P., Forget, P., 2008. Wave- and current-induced bottom shear stress distribution in the Gulf of Lions. Cont. Shelf Res. 28 (15), 1920-1934.

Durrieu de Madron, X., Abassi, A., Heussner, S., Monaco, A., Aloisi, J.C., Radakovitch, O., Giresse, P., Buscail, R., Kerherve, P., 2000. Particulate matter and organic carbon budgets for the Gulf of Lions (NW Mediterranean). Oceanol. Acta 23 (6), 717-730. 
Durrieu de Madron, X., Denis, L., Diaz, F., Garcia, N., Guieu, C., Grenz, C., Loÿe-Pilot, M.D., Ludwig, W., Moutin, T., Raimbault, P., Ridame, C., 2003. Nutrients and carbon budgets for the Gulf of Lion during the Moogli cruises. Oceanol. Acta 26 (4), 421433.

Eberwein, A., Mackensen, A., 2006. Regional primary productivity differences off Morocco (NW-Africa) recorded by modern benthic foraminifera and their stable carbon isotopic composition. Deep-Sea Res. I 53 (8), 1379-1405.

Eisma, D., 1993. Suspended matter in the aquatic environment. Springer, Berlin, New York, p. 315 .

Fontanier, C., Jorissen, F.J., Chaillou, G., David, C., Anschutz, P., Lafon, V., 2003. Seasonal and interannual variability of benthic foraminiferal faunas at $550 \mathrm{~m}$ depth in the Bay of Biscay. Deep-Sea Res. I 50 (4), 457-494.

Fontanier, C., Jorissen, F., Geslin, E., Zaragosi, S., Duchemin, G., Laversin, M., Gaultier, M., 2008a. Live and dead foraminiferal faunas from Saint-Tropez Canyon (Bay of Fréjus): Observations based on situ and incubated cores. J. Foraminifer. Res. 38 (2), 137-156.

Fontanier, C., Jorissen, F.J., Lansard, B., Mouret, A., Buscail, R., Schmidt, S., Kerhervé, P., Buron, F., Zaragosi, S., Hunault, G., Ernoult, E., Artero, C., Anschutz, P., Rabouille, C., 2008b. Live foraminifera from the open slope between Grand Rhône and Petit Rhône Canyons (Gulf of Lions, NW Mediterranean). Deep-Sea Res. I 55 (11), 15321553.

Frezza, V., Carboni, M.G., 2009. Distribution of recent foraminiferal assemblages near the Ombrone River mouth (Northern Tyrrhenian Sea, Italy). Rev. Micropaleontol. 52 (1), 43-66.

Goineau, A., Fontanier, C., Jorissen, F.J., Lansard, B., Buscail, R., Mouret, A., Kerhervé, P., Zaragosi, S., Ernoult, E., Artéro, C., Anschutz, P., Metzger, E., Rabouille, C., 2011. 
Live (stained) benthic foraminifera from the Rhône prodelta (Gulf of Lion, NW Mediterranean): Environmental controls on a river-dominated shelf. J. Sea Res. 65 (1), $58-75$.

Goineau, A., Fontanier, C., Jorissen, F.J., Buscail, R., Kerhervé, P., Cathalot, C., Pruski, A.M., Lantoine, F., Bourgeois, S., Metzger, E., Legrand, E., Rabouille, C., 2012. Temporal variability of live (stained) benthic foraminiferal faunas in a riverdominated shelf: faunal response to rapid changes of the river influence (Rhône prodelta, NW Mediterranean). Biogeosciences 9, 1367-1388.

Gooday, A.J., 2003. Benthic Foraminifera (Protista) as tools in Deep-water Palaeoceanography: Environmental Influences on Faunal Characteristics. Adv. Mar. Biol. 46, 1-90.

Got, H., Aloisi, J.C., 1990. The Holocene sedimentation on the Gulf of Lions margin: a quantitative approach. Cont. Shelf Res. 10 (9-11), 841-855.

Harmelin-Vivien, M., Loizeau, V., Mellon, C., Beker, B., Arlhac, D., Bodiguel, X., Ferraton, F., Hermand, R., Philippon, X., Salen-Picard, C., 2008. Comparison of C and N stable isotope ratios between surface particulate organic matter and microphytoplankton in the Gulf of Lions (NW Mediterranean). Cont. Shelf Res. 28 (15), 1911-1919.

Jorissen, F.J., 1987. The distribution of benthic foraminifera in the Adriatic Sea. Mar. Micropaleontol. 12, 21-48.

Jorissen, F.J., 1988. Benthic foraminifera from the Adriatic Sea; Principles of phenotypic variation. PhD Thesis, Utrecht Micropaleontology Bulletin 37, p. 176

Jorissen, F.J., Wittling, I., 1999. Ecological evidence from live-dead comparisons of benthic foraminiferal faunas off Cape Blanc (Northwest Africa). Palaeogeogr. Palaeocl. Palaeoecol. 149 (1-4), 151-170. 
Jorissen, F.J., Barmawidjaja, D.M., Puskaric, S., van der Zwaan, G.J., 1992. Vertical distribution of benthic foraminifera in the northern Adriatic Sea: The relation with the organic flux. Mar. Micropaleontol. 19 (1-2), 131-146.

Jorissen, F.J., Fontanier, C., Thomas, E., Hillaire-Marcel, C., de Vernal, A., 2007. Paleoceanographical proxies based on deep-sea benthic foraminiferal assemblage characteristics. In: Hillaire-Marcel, C., de Vernal, A. (Eds.), Proxies in Late Cenozoic Paleoceanography. Elsevier, Amsterdam, pp. 263-325.

Kitazato, H., Nomaki, H., Heinz, P., Nakatsuka, T., 2003. The role of benthic foraminifera in deep-sea food webs at the sediment-water interface: results from in situ feeding experiments in Sagami Bay. Frontier Research on Earth Evolution 1, 227-232.

Kruit, C., 1955. Sediments of the Rhône delta: Grain size and microfauna. Mouton \& Co, La Haye, p. 157.

L'Homer, A., 1993. Notice de la Carte Géologique au 1/50 000, Feuille du Grau du Roi. BRGM, p. 93.

Langezaal, A.M., Jorissen, F.J., Braun, B., Chaillou, G., Fontanier, C., Anschutz, P., van der Zwaan, G.J., 2006. The influence of seasonal processes on geochemical profiles and foraminiferal assemblages on the outer shelf of the Bay of Biscay. Cont. Shelf Res. 26 (15), 1730-1755.

Lochet, F., Leveau, M., 1990. Transfers between a eutrophic ecosystem, the river Rhône, and an oligotrophic ecosystem, the north-western Mediterranean Sea. Hydrobiologia 207 (1), 95-103.

Loubere, P., 1989. Bioturbation and sedimentation rate control of benthic microfossil taxon abundances in surface sediments: A theoretical approach to the analysis of species microhabitats. Mar. Micropaleontol. 14 (4), 317-325. 
Mendes, I., Gonzalez, R., Dias, J.M.A., Lobo, F., Martins, V., 2004. Factors influencing recent benthic foraminifera distribution on the Guadiana shelf (Southwestern Iberia). Mar. Micropaleontol. 51 (1-2), 171-192.

Millot, C., 1990. The Gulf of Lions' hydrodynamics. Cont. Shelf Res. 10 (9-11), 885-894.

Millot, C., 1999. Circulation in the Western Mediterranean Sea. J. Marine Syst. 20 (1-4), 423442.

Miralles, J., Radakovitch, O., Aloisi, J.C., $2005 .{ }^{210} \mathrm{~Pb}$ sedimentation rates from the Northwestern Mediterranean margin. Mar. Geol. 216 (3), 155-167.

Mojtahid, M., Jorissen, F., Lansard, B., Fontanier, C., Bombled, B., Rabouille, C., 2009. Spatial distribution of live benthic foraminifera in the Rhône prodelta: Faunal response to a continental-marine organic matter gradient. Mar. Micropaleontol. 70 (34), 177-200.

Mojtahid, M., Jorissen, F., Lansard, B., Fontanier, C., 2010. Microhabitat selection of benthic foraminifera in sediments off the Rhône River mouth (NW Mediterranean). J. Foraminifer. Res. 40, 231-246.

Murray, J.W., 1991. Ecology and Palaeoecology of benthic foraminifera. Longman Scientific \& Technical, Harlow, p. 397

Murray, J.W., 2006. Ecology and Applications of Benthic Foraminifera. Cambridge University Press, Cambridge, p. 426.

Murray, J.W., Alve, E., 1999. Natural dissolution of modern shallow water benthic foraminifera: taphonomic effects on the palaeoecological record. Palaeogeogr. Palaeocl. Palaeoecol. 146 (1-4), 195-209.

Naudin, J.J., Cauwet, G., Chrétiennot-Dinet, M.J., Deniaux, B., Devenon, J.L., Pauc, H., 1997. River Discharge and Wind Influence Upon Particulate Transfer at the Land- 
Ocean Interaction: Case Study of the Rhône River Plume. Estuar. Coast. Shelf S. 45 (3), 303-316.

Nomaki, H., Heinz, P., Hemleben, C., Kitazato, H., 2005a. Behavior and response of deep-sea benthic foraminifera to freshly supplied organic matter: A laboratory feeding experiment in microcosm environments. J. Foraminifer. Res. 35 (2), 103-113.

Nomaki, H., Heinz, P., Nakatsuka, T., Shimanaga, M., Kitazato, H., 2005b. Species-specific ingestion of organic carbon by deep-sea benthic foraminifera and meiobenthos: In situ tracer experiments. Limnol. Oceanogr. 50 (1), 134-146.

Nomaki, H., Heinz, P., Nakatsuka, T., Shimanaga, M., Ohkouchi, N., Ogawa, N.O., Kogure, K., Ikemoto, E., Kitazato, H., 2006. Different ingestion patterns of ${ }^{13} \mathrm{C}$-labeled bacteria and algae by deep-sea benthic foraminifera. Mar. Ecol. Prog. Ser. 310, 95108.

Pont, D., Simonnet, J.P., Walter, A.V., 2002. Medium-term Changes in Suspended Sediment Delivery to the Ocean: Consequences of Catchment Heterogeneity and River Management (Rhône River, France). Estuar. Coast. Shelf S. 54 (1), 1-18.

Rabineau, M., Berné, S., Aslanian, D., Olivet, J.-L., Joseph, P., Guillocheau, F., Bourillet, J.F., Ledrezen, E., Granjeon, D., 2005. Sedimentary sequences in the Gulf of Lion: A record of 100,000 years climatic cycles. Mar. Petrol. Geol. 22 (6-7), 775-804.

Radakovitch, O., Charmasson, S., Arnaud, M., Bouisset, P., 1999. ${ }^{210} \mathrm{~Pb}$ and caesium accumulation in the Rhône delta sediments. Estuar. Coast. Shelf S. 48 (1), 77-92.

Rossi, V., Vaiani, S.C., 2008. Benthic foraminiferal evidence of sediment supply changes and fluvial drainage reorganization in Holocene deposits of the Po Delta, Italy. Mar. Micropaleontol. 69 (2), 106-118.

Rossiaud, J., 1994. Réalités et imaginaire d'un fleuve. Recherches sur le Rhône médiéval. PhD Thesis, Université de Paris I, Paris. 
Sabatier, F., Suanez, S., 2003. Evolution of the Rhône delta coast since the end of the $19^{\text {th }}$ century. Géomorphologie 47, 283-300.

Sabatier, F., Maillet, G., Provansal, M., Fleury, T.-J., Suanez, S., Vella, C., 2006. Sediment budget of the Rhône delta shoreface since the middle of the $19^{\text {th }}$ century. Mar. Geol. $234(1-4), 143-157$.

Schmiedl, G., de Bovée, F., Buscail, R., Charrière, B., Hemleben, C., Medernach, L., Picon, P., 2000. Trophic control of benthic foraminiferal abundance and microhabitat in the bathyal Gulf of Lions, western Mediterranean Sea. Mar. Micropaleontol. 40 (3), 167188.

Schröder, C.J., 1988. Subsurface preservation of agglutinated foraminifera in the northwest Atlantic Ocean. Abhandlungen der Geologischen Bundesanstalt 41, 325-336.

Stouthamer, E., 2001. Sedimentary products of avulsions in the Holocene Rhine-Meuse Delta, The Netherlands. Sediment. Geol. 145 (1-2), 73-92.

van der Zwaan, G.J., Jorissen, F., 1991. Biofacial patterns in river-induced shelf anoxia. In: Modern and Ancient Continental Shelf Anoxia. Geological Society, Special Publication 58, 65-82.

Vella, C., Fleury, T.-J., Raccasi, G., Provansal, M., Sabatier, F., Bourcier, M., 2005. Evolution of the Rhône delta plain in the Holocene. Mar. Geol. 222-223 (1-4), 235265.

Zuo, Z., Eisma, D., Berger, G.W., 1991. Determination of sediment accumulation and mixing rates in the Gulf of Lions, Mediterranean-sea. Oceanol. Acta 14 (3), 253-262.

Zuo, Z., Eisma, D., Gieles, R., Beks, J., 1997. Accumulation rates and sediment deposition in the northwestern Mediterranean. Deep-Sea Res. II 44 (3-4), 597-609. 


\section{Figure captions}

Figure 1: Location of the 41 stations (e.g., M1, M2, BT1...) and of the long sediment core (RHS-KS57) investigated in the study area. Location of silty / sandy patches, palaeo-channels and relict delta fronts after Vella et al. (2005) and Berné et al. (2007). Yearly-mean position of the Rhône River plume after Naudin et al. (1997). The circular diagram indicates the mean frequency and direction of swells (Brunel, 2010), and black arrows indicate longshore currents (Sabatier and Suanez, 2003); NMC: North Mediterranean Current.

Figure 2: Ecological indices describing dead fossilising foraminiferal assemblages from the 3 to 4 or 2 to $5 \mathrm{~cm}$ sediment layers. (a) Absolute foraminiferal abundances (D) normalised for a sediment volume of $100 \mathrm{~cm}^{3}$; (b) Number of species (S); (c)-(d) Shannon (H) and Evenness (E) indices.

Figure 3: Two-way cluster analysis (Q-mode and R-mode) using unweighted pair-group average method, based on the percentage contributions to the dead fossilising fauna of the 23 fossilising major species ( $\geq 5 \%$ in at least one station) from the $>150 \mu \mathrm{m}$ size fraction. The location of the groups of stations defined by Q-mode clustering is represented on the map.

Figure 4: Spatial distribution (cumulative percentages) in the fossilising dead and living faunas sampled in June 2005 and September 2006 of the groups of species determined by Rmode cluster analysis. For each group of species or single species, larger white crosses correspond to thanatoacies (i.e., stations) where these species are present in highest percentages in the fossilising dead faunas. Cluster 1 (Thanatofacies A, River mouth): Ammonia beccarii forma beccarii, Ammonia tepida; Cluster 2 (Thanatofacies B, Coastal area): Bulimina elongata, Elphidium spp., Quinqueloculina lata; Cluster 3 (Thanatofacies C, Rhône River plume): Nonion fabum, Rectuvigerina phlegeri, Valvulineria bradyana; Cluster 4 (Thanatofacies D, Outer shelf): Ammonia beccarii forma inflata, Bigenerina nodosaria, Bulimina aculeata, Bulimina marginata, Hyalinea balthica, Melonis barleeanus, 
Pseudoeponides falsobeccarii, Quinqueloculina seminula and Textularia agglutinans; Single species: Nonionella turgida (Thanatofacies C, Rhône river Plume), Pyrgo oblonga (Thanatofacies C, Rhône river Plume) and Cassidulina carinata (Thanatofacies D, Outer shelf).

Figure 5: Succession along a river mouth - offshore transect of the groups of species (cumulative percentages in the fossilising dead faunas) determined by R-mode cluster analysis. 
Figure 1

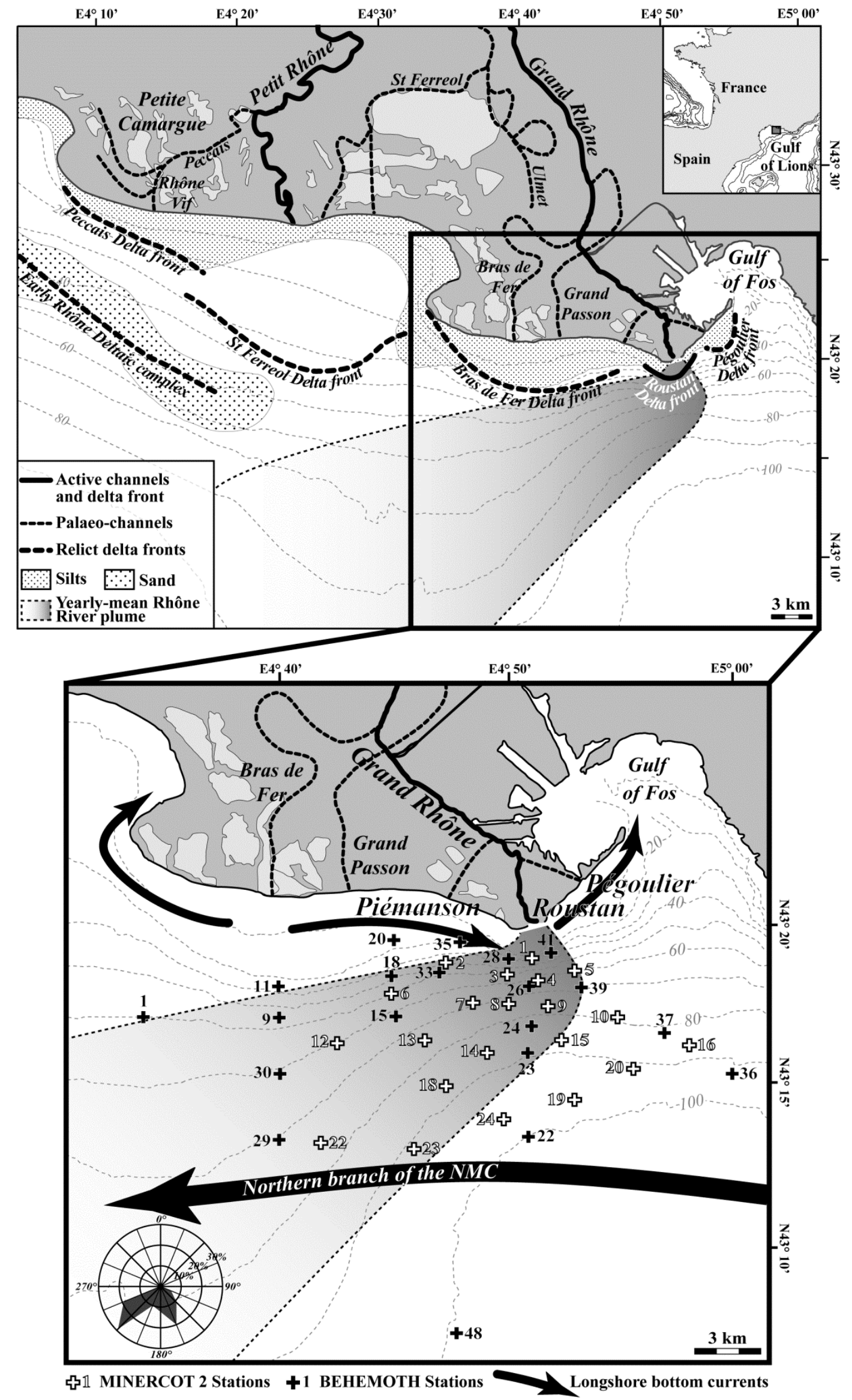


Figure 2

(a) Dead foraminiferal abundances

(No ind./100 $\mathrm{cm}^{3}$ of sediment)

(b) Species richness $\mathrm{S}$
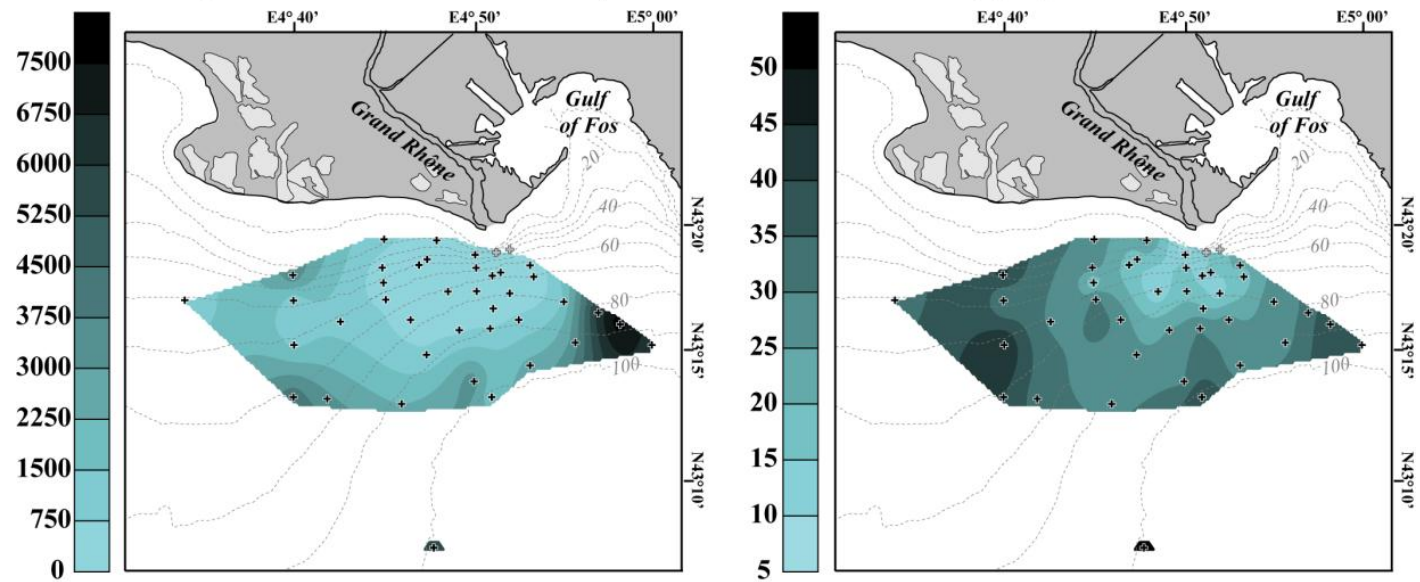

(c) Shannon Index $\mathrm{H}$

(d) Evenness Index E
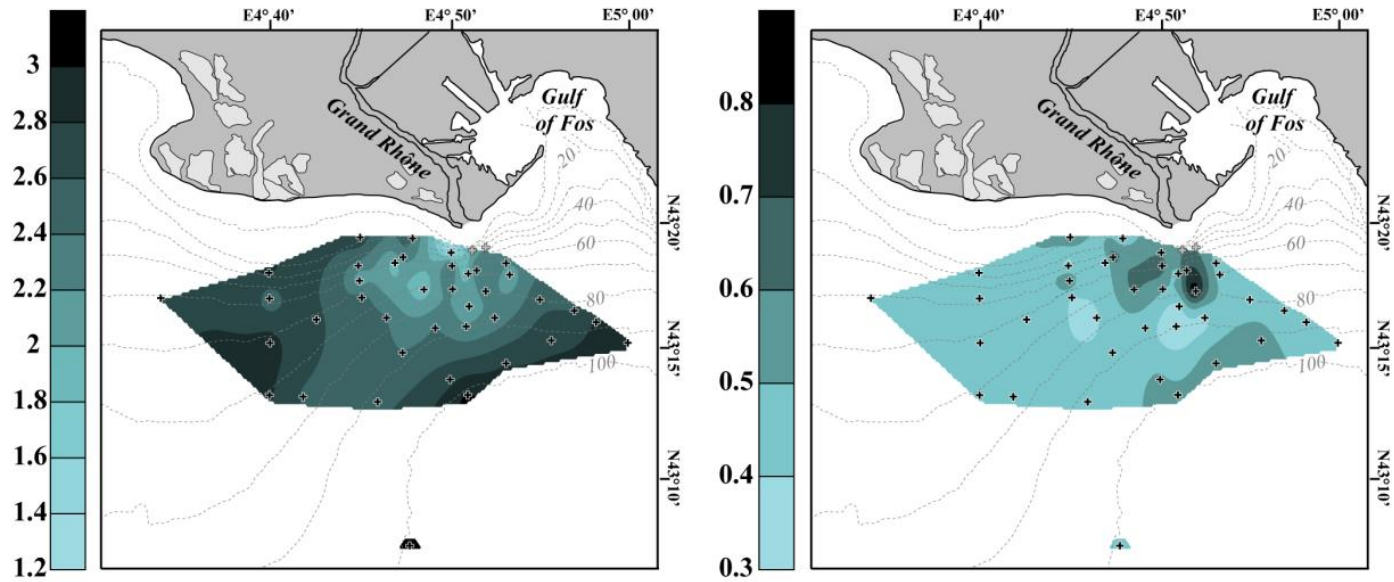
Figure 3

Q-mode clustering

Unweighted pair-group average
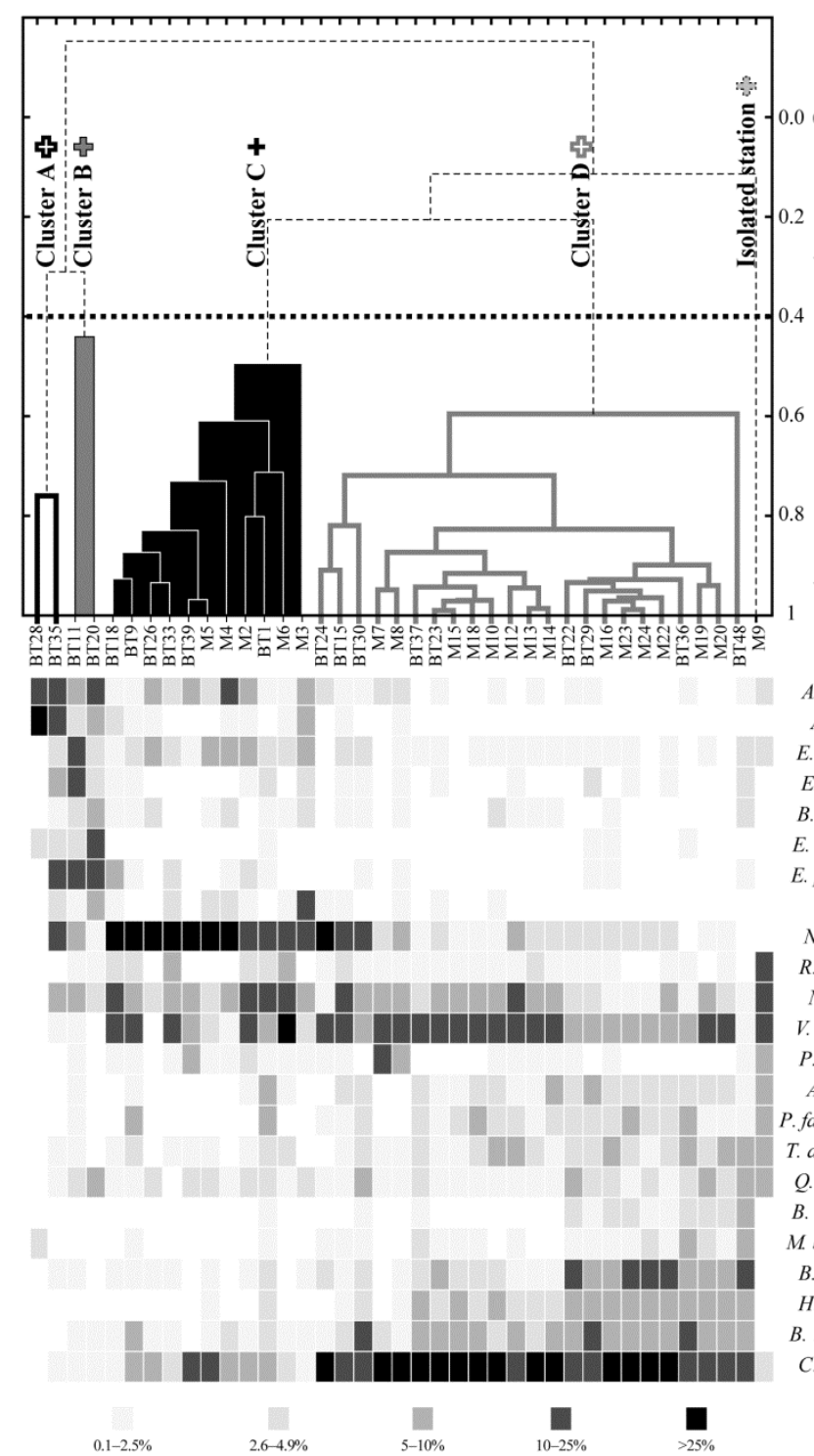

Relative contribution (\%) to the total dead fossilising fauna of the 23 major species
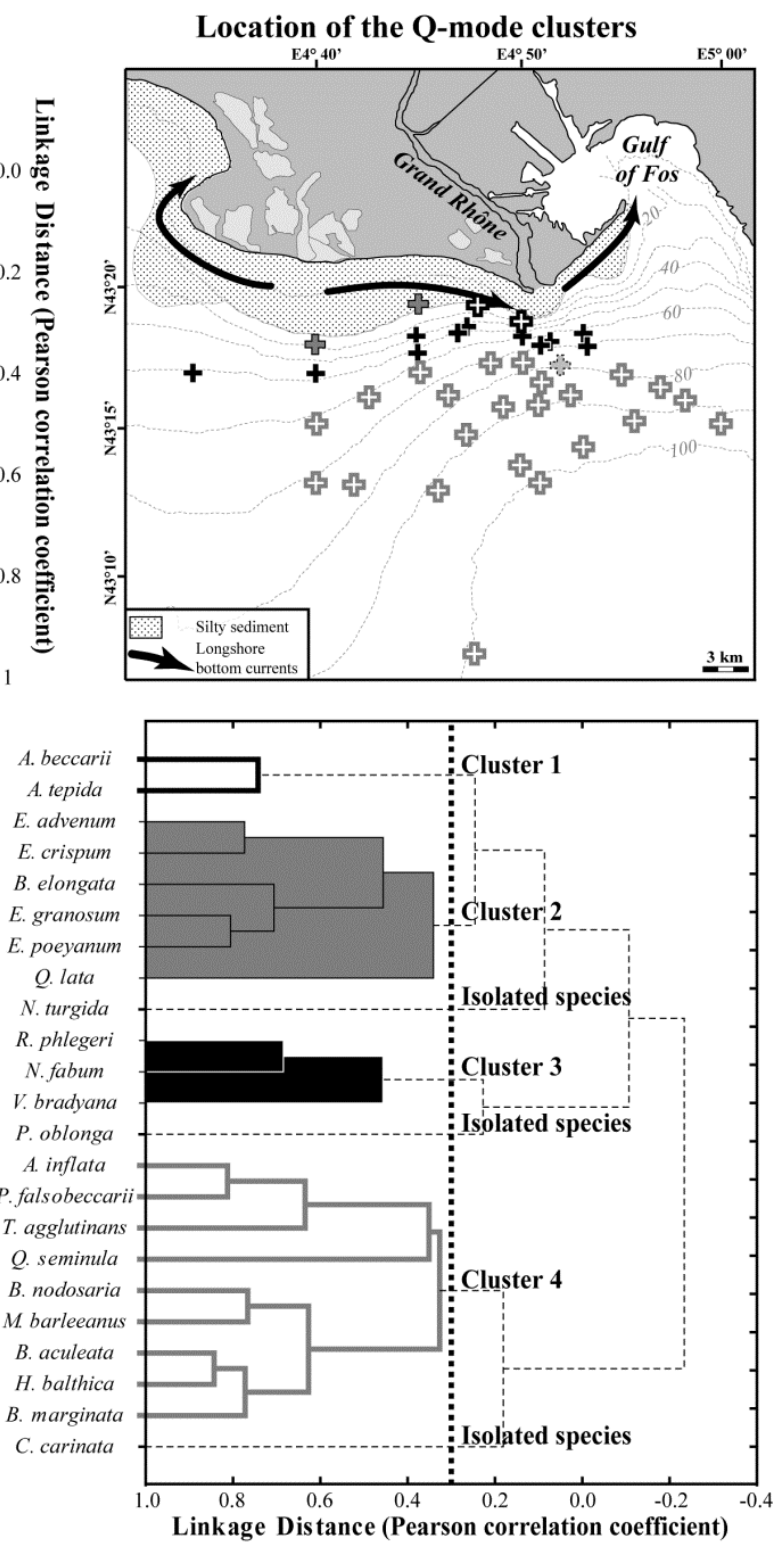

R-mode clustering

Unweighted pair-group average 
Figure 4

$\%$ Dead assemblage

\% Living assemblage
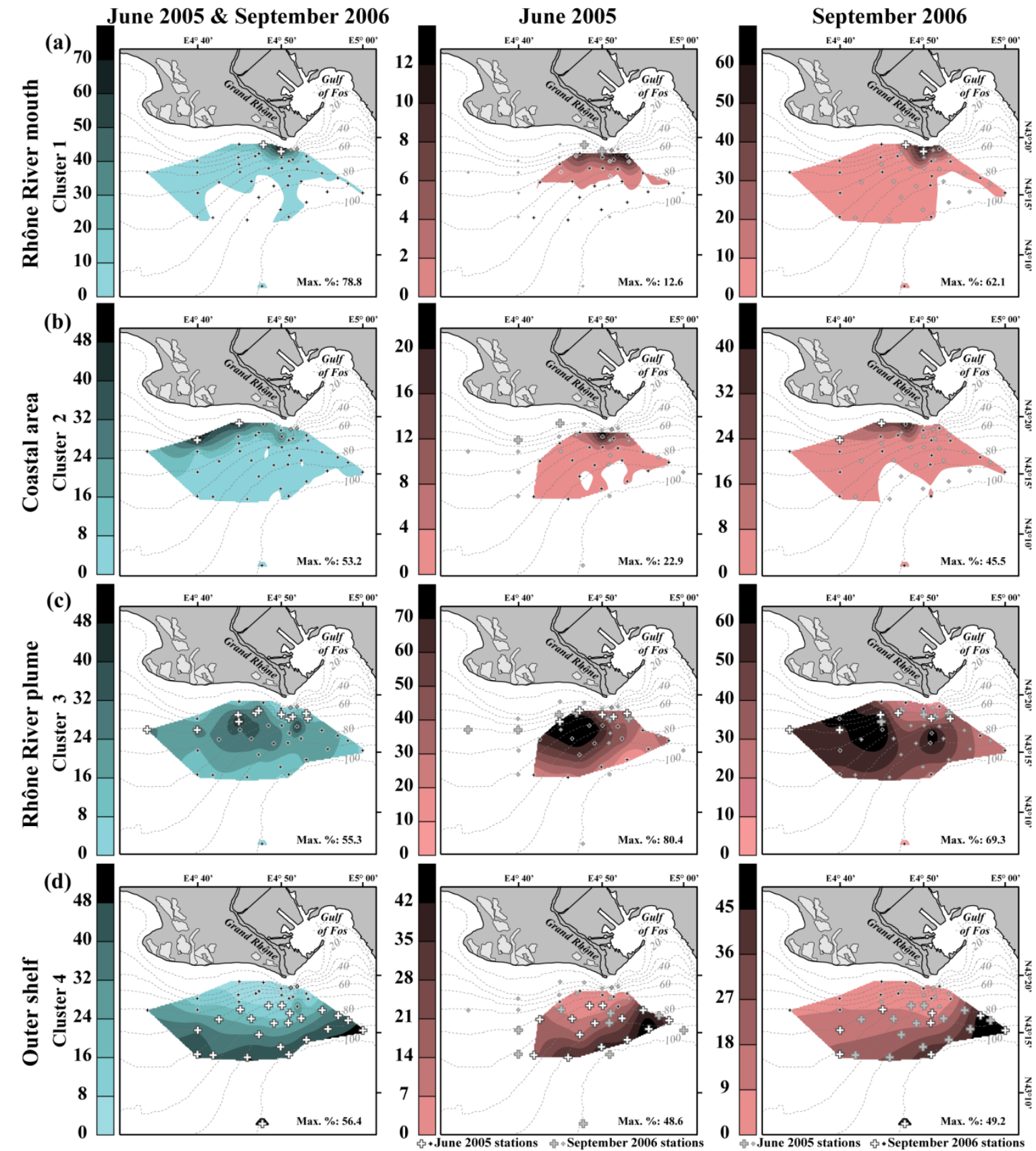
Figure 4 (continued)

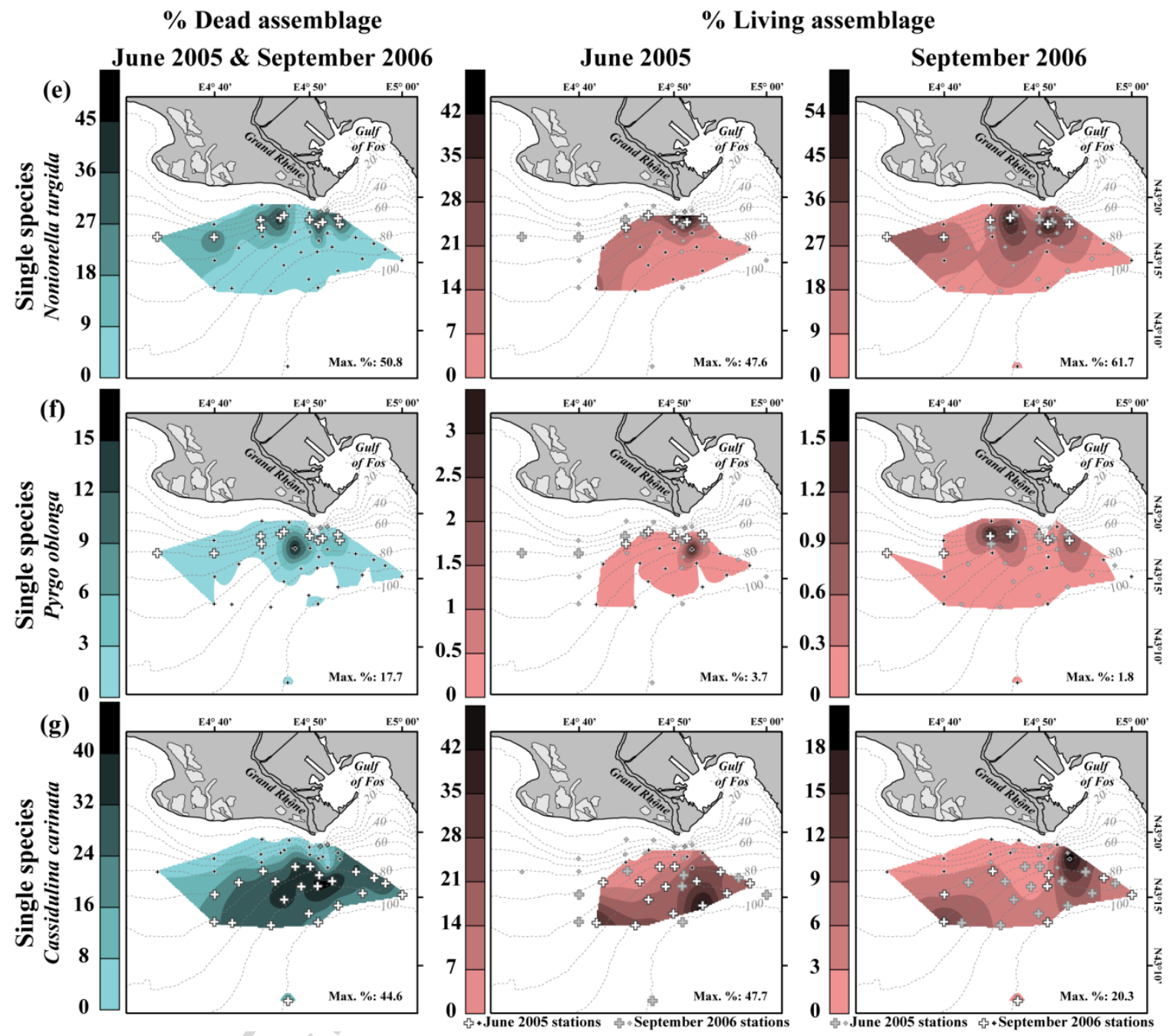


Figure 5

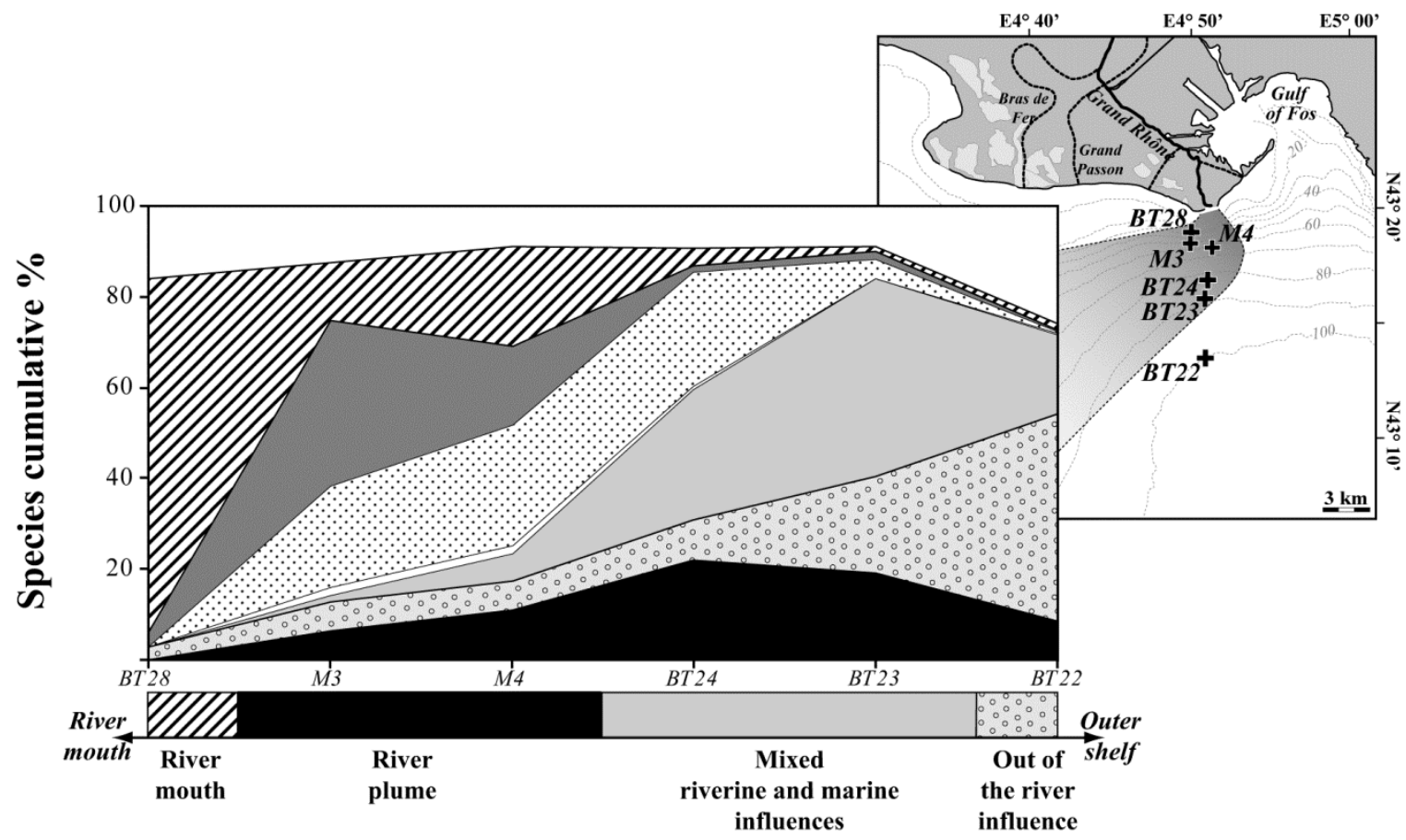

—\% "River plume" $\square \%$ Cassidulina carinata $\mathbf{\square} \%$ Nonionella turgida $\square \%$ "River mouth" 무\% "Outer shelf" $\square \%$ Pyrgo oblonga $\square \%$ "Coastal area" 
Table 1

Location and characteristics of the 41 stations sampled during the MINERCOT 2 (June 2005) and BEHEMOTH (September 2006) cruises.

\begin{tabular}{|c|c|c|c|c|}
\hline \multicolumn{5}{|c|}{ MINERCOT 2 cruise - June 2005} \\
\hline Station & Lat. $\left({ }^{\circ} \mathrm{N}\right)$ & Long. $\left({ }^{\circ} \mathrm{E}\right)$ & $\begin{array}{l}\text { Depth } \\
\text { (m) }\end{array}$ & $\begin{array}{l}\text { Dist./river } \\
\text { mouth }(\mathrm{km})\end{array}$ \\
\hline M1 & $43^{\circ} 18.9^{\prime}$ & $4^{\circ} 51.2^{\prime}$ & 20 & 1.9 \\
\hline M2 & $43^{\circ} 18.6^{\prime}$ & $4^{\circ} 47.4^{\prime}$ & 40 & 5 \\
\hline M3 & $43^{\circ} 18.3^{\prime}$ & $4^{\circ} 50.1^{\prime}$ & 53 & 3 \\
\hline M4 & $43^{\circ} 18.2^{\prime}$ & $4^{\circ} 51.5^{\prime}$ & 60 & 3.2 \\
\hline M5 & $43^{\circ} 18.4^{\prime}$ & $4^{\circ} 53.1^{\prime}$ & 63 & 4.2 \\
\hline M6 & $43^{\circ} 17.7^{\prime}$ & $4^{\circ} 45.0^{\prime}$ & 40 & 8.6 \\
\hline M7 & $43^{\circ} 17.4^{\prime}$ & $4^{\circ} 48.6^{\prime}$ & 65 & 5.3 \\
\hline M8 & $43^{\circ} 17.4^{\prime}$ & $4^{\circ} 50.2^{\prime}$ & 65 & 4.5 \\
\hline M9 & $43^{\circ} 17.3^{\prime}$ & $4^{\circ} 52.0^{\prime}$ & 65 & 4.9 \\
\hline M10 & $43^{\circ} 17.0^{\prime}$ & $4^{\circ} 55.0^{\prime}$ & 80 & 7.8 \\
\hline M12 & $43^{\circ} 16.2^{\prime}$ & $4^{\circ} 42.6^{\prime}$ & 58 & 12.8 \\
\hline M13 & $43^{\circ} 16.3^{\prime}$ & $4^{\circ} 46.5^{\prime}$ & 75 & 8.7 \\
\hline M14 & $43^{\circ} 15.9^{\prime}$ & $4^{\circ} 49.3^{\prime}$ & 85 & 7.6 \\
\hline M15 & $43^{\circ} 16.3^{\prime}$ & $4^{\circ} 52.5^{\prime}$ & 89 & 6.9 \\
\hline M16 & $43^{\circ} 16.1^{\prime}$ & $4^{\circ} 58.1^{\prime}$ & 83 & 12 \\
\hline M18 & $43^{\circ} 14.9^{\prime}$ & $4^{\circ} 47.4^{\prime}$ & 85 & 10.1 \\
\hline M19 & $43^{\circ} 14.5^{\prime}$ & $4^{\circ} 53.1^{\prime}$ & 98 & 10.3 \\
\hline M20 & $43^{\circ} 15.4^{\prime}$ & $4^{\circ} 55.7^{\prime}$ & 92 & 10.6 \\
\hline M22 & $43^{\circ} 13.2^{\prime}$ & $4^{\circ} 41.8^{\prime}$ & 74 & 17.1 \\
\hline M23 & $43^{\circ} 13.0^{\prime}$ & $4^{\circ} 46.0^{\prime}$ & 90 & 14.1 \\
\hline M24 & $43^{\circ} 13.9^{\prime}$ & $4^{\circ} 50.0^{\prime}$ & 95 & 10.9 \\
\hline
\end{tabular}

\begin{tabular}{lllll}
\hline \multicolumn{6}{l}{ BEHEMOTH cruise - September 2006 } \\
\hline Station & Lat. $\left({ }^{\circ} \mathrm{N}\right)$ & Long. $\left({ }^{\circ} \mathrm{E}\right)$ & $\begin{array}{l}\text { Depth } \\
(\mathrm{m})\end{array}$ & $\begin{array}{l}\text { Dist./river } \\
\text { mouth }(\mathrm{km})\end{array}$ \\
\hline BT1 & $43^{\circ} 17.0^{\prime}$ & $4^{\circ} 34.0^{\prime}$ & 49 & 22.2 \\
BT9 & $43^{\circ} 17.0^{\prime}$ & $4^{\circ} 40.0^{\prime}$ & 44 & 14.6 \\
BT11 & $43^{\circ} 18.0^{\prime}$ & $4^{\circ} 40.0^{\prime}$ & 26 & 14 \\
BT15 & $43^{\circ} 17.1^{\prime}$ & $4^{\circ} 45.1^{\prime}$ & 60 & 8.9 \\
BT18 & $43^{\circ} 18.3^{\prime}$ & $4^{\circ} 45.0^{\prime}$ & 37 & 7.5 \\
BT20 & $43^{\circ} 19.4^{\prime}$ & $4^{\circ} 45.1^{\prime}$ & 15 & 7.8 \\
BT22 & $43^{\circ} 13.3^{\prime}$ & $4^{\circ} 51.0^{\prime}$ & 98 & 11.4 \\
BT23 & $43^{\circ} 15.9^{\prime}$ & $4^{\circ} 51.0^{\prime}$ & 86 & 5.7 \\
BT24 & $43^{\circ} 16.8^{\prime}$ & $4^{\circ} 51.1^{\prime}$ & 79 & 4.4 \\
BT26 & $43^{\circ} 18.0^{\prime}$ & $4^{\circ} 51.0^{\prime}$ & 62 & 2.8 \\
BT28 & $43^{\circ} 18.8^{\prime}$ & $4^{\circ} 50.1^{\prime}$ & 18 & 1 \\
BT29 & $43^{\circ} 13.3^{\prime}$ & $4^{\circ} 40.0^{\prime}$ & 68 & 17.9 \\
BT30 & $43^{\circ} 15.3^{\prime}$ & $4^{\circ} 40.0^{\prime}$ & 60 & 16.5 \\
BT33 & $43^{\circ} 18.4^{\prime}$ & $4^{\circ} 47.1^{\prime}$ & 47 & 5.4 \\
BT35 & $43^{\circ} 19.3^{\prime}$ & $4^{\circ} 48.0^{\prime}$ & 20 & 3.1 \\
BT36 & $43^{\circ} 15.3^{\prime}$ & $5^{\circ} 00.0^{\prime}$ & 89 & 14.4 \\
BT37 & $43^{\circ} 16.6^{\prime}$ & $4^{\circ} 57.0^{\prime}$ & 80 & 9.6 \\
BT39 & $43^{\circ} 17.9^{\prime}$ & $4^{\circ} 53.3^{\prime}$ & 69 & 4.1 \\
BT41 & $43^{\circ} 19.0^{\prime}$ & $4^{\circ} 52.0^{\prime}$ & 30 & 1.5 \\
BT48 & $43^{\circ} 07.4^{\prime}$ & $4^{\circ} 47.8^{\prime}$ & 100 & 22.4 \\
\hline
\end{tabular}


Table 2

Bray-Curtis dissimilarity values

\begin{tabular}{llll}
\hline \multicolumn{2}{l}{ MINERCOT 2 cruise - June 2005 } & \multicolumn{2}{l}{ BEHEMOTH cruise - September 2006 } \\
\hline Station & Bray-Curtis dissimilarity & Station & Bray-Curtis dissimilarity \\
\hline M2 & 0.37 & BT1 & 0.44 \\
M3 & 0.41 & BT9 & 0.41 \\
M4 & 0.41 & BT11 & 0.70 \\
M5 & 0.44 & BT15 & 0.54 \\
M6 & 0.36 & BT18 & 0.41 \\
M7 & 0.61 & BT20 & 0.61 \\
M8 & 0.50 & BT22 & 0.42 \\
M9 & 0.43 & BT23 & 0.60 \\
M10 & 0.36 & BT24 & 0.55 \\
M12 & 0.48 & BT26 & 0.26 \\
M13 & 0.67 & BT29 & 0.44 \\
M14 & 0.55 & BT30 & 0.52 \\
M15 & 0.43 & BT33 & 0.31 \\
M16 & 0.43 & BT35 & 0.42 \\
M18 & 0.47 & BT36 & 0.49 \\
M19 & 0.47 & BT37 & 0.47 \\
M20 & 0.23 & BT39 & 0.29 \\
M22 & 0.35 & BT48 & 0.34 \\
M23 & 0.33 & & \\
M24 & 0.39 & & \\
\hline
\end{tabular}


Table 3

Relative abundances of major fossilising species in the living ("L"; Mojtahid et al., 2009) and the dead ("D") faunas (this study) of June 2005. Grey boxes: percentages $\geq 2.5 \%$; Bold values: percentages $\geq 5 \%$.

\begin{tabular}{|c|c|c|c|c|c|c|c|c|c|c|c|c|c|c|c|c|c|c|c|c|}
\hline \multirow{2}{*}{$\begin{array}{l}\text { Stations } \\
\% \text { Fossilising fauna }\end{array}$} & \multicolumn{2}{|l|}{ M2 } & \multicolumn{2}{|l|}{ M3 } & \multicolumn{2}{|l|}{ M4 } & \multicolumn{2}{|l|}{ M5 } & \multicolumn{2}{|l|}{ M6 } & \multicolumn{2}{|l|}{ M7 } & \multicolumn{2}{|l|}{ M8 } & \multicolumn{2}{|l|}{ M9 } & \multicolumn{2}{|l|}{ M10 } & \multicolumn{2}{|l|}{ M12 } \\
\hline & $L$ & $\mathrm{D}$ & $L$ & $\mathrm{D}$ & $L$ & $\mathrm{D}$ & $L$ & $\mathrm{D}$ & $L$ & $\mathrm{D}$ & $L$ & $\mathrm{D}$ & $L$ & $\mathrm{D}$ & $L$ & $\mathrm{D}$ & $L$ & $\mathrm{D}$ & $L$ & $\mathrm{D}$ \\
\hline Ammonia spp.* & 9.9 & 10.2 & 7.0 & 12.9 & 9.1 & 22.2 & 12.6 & 3.8 & 1.5 & 2.7 & 1.0 & 3.2 & 1.9 & 3.2 & 0.5 & 3.1 & - & 0.5 & - & - \\
\hline Ammonia beccarii f. inflata & - & 0.4 & - & - & - & - & - & - & 0.2 & 1.1 & - & & & - & 1.9 & 9.4 & 1.9 & 2.9 & 5.3 & 0.5 \\
\hline Bolivina alata & - & - & - & - & 0.2 & - & 0.2 & - & - & - & - & & & - & 0.5 & - & 0.2 & - & 0.1 & - \\
\hline Bulimina aculeata & - & 0.8 & 0.3 & 1.6 & 0.2 & - & - & 0.8 & 0.6 & - & 0.1 & & - & 1.4 & 3.2 & - & 5.2 & 2.9 & 4.5 & 1.0 \\
\hline Bulimina elongata & 0.2 & - & 9.2 & 3.2 & 2.1 & 3.2 & 2.6 & 0.8 & 0.1 & 1.1 & & & 0.5 & 0.5 & 0.5 & - & 0.7 & 2.9 & - & 0.5 \\
\hline Bulimina marginata & 0.1 & 0.4 & 1.3 & 1.6 & - & 4.8 & - & 2.3 & - & 1.1 & 0.9 & 3.2 & 0.7 & 2.3 & 0.9 & - & 2.5 & 4.3 & 1.6 & 8.1 \\
\hline Cassidulina carinata & 0.2 & 7.0 & 1.0 & 1.6 & 2.1 & 6.3 & 13.8 & 21.8 & 0.6 & 4.8 & 5.1 & 35.5 & 8.7 & 37.0 & 23.1 & 3.1 & 22.3 & 33.3 & 3.1 & 23.8 \\
\hline Elphidium spp. & 4.6 & 13.9 & 3.2 & 11.3 & 1.1 & 9.5 & 0.7 & 5.3 & 1.4 & 4.3 & 0.7 & - & 1.6 & 2.7 & 0.5 & 3.1 & 0.2 & 1.0 & 2.0 & 2.9 \\
\hline Hyalinea balthica & - & - & - & - & - & - & - & 0.8 & - & & 0.1 & - & 0.1 & 0.5 & 0.5 & - & 0.5 & 5.2 & 0.2 & 2.9 \\
\hline Melonis barleeanus & 0.8 & - & 1.0 & - & - & - & - & - & - & - & 0.3 & - & - & - & - & - & - & - & 0.5 & 0.5 \\
\hline Nonion fabum & 53.2 & 18.9 & 34.1 & 6.5 & 28.5 & 9.5 & 33.0 & 3.0 & 55.2 & 17.0 & 54.6 & 9.7 & 42.5 & 6.8 & 25.0 & 21.9 & 16.3 & 7.1 & 41.4 & 10.5 \\
\hline Nonionella turgida & 15.5 & 17.6 & 31.5 & 22.6 & 47.6 & 27.0 & 21.9 & 36.8 & 11.7 & 11.7 & 7.6 & 3.2 & 12.4 & 9.6 & 10.6 & - & 2.9 & 1.4 & 9.3 & 6.7 \\
\hline Pseudoeponides falsobeccarii & - & - & - & - & 0.2 & - & - & - & 0.2 & - & 0.1 & - & - & - & 2.8 & 9.4 & 1.2 & 3.3 & 0.9 & 3.3 \\
\hline Rectuvigerina phlegeri & 5.7 & 3.7 & - & - & 0.2 & - & 0.7 & - & 6.4 & 6.4 & 1.2 & 1.6 & 0.8 & 0.9 & 4.2 & 15.6 & 3.8 & 1.0 & 6.7 & 1.4 \\
\hline Valvulineria bradyana & 7.1 & 13.9 & - & - & 1.6 & 1.6 & 5.2 & 3.8 & 18.7 & 31.9 & 24.6 & 16.1 & 25.1 & 13.7 & 13.4 & 12.5 & 7.1 & 12.4 & 17.6 & 14.8 \\
\hline Pyrgo oblonga & - & 3.7 & - & 1.6 & - & 1.6 & - & 1.5 & - & 0.5 & 0.4 & 17.7 & - & 8.2 & 3.7 & 6.3 & 0.5 & 0.5 & 0.1 & - \\
\hline Quinqueloculina lata & 1.0 & 1.2 & 10.5 & 22.6 & 6.6 & 4.8 & 6.2 & 4.5 & 0.8 & 1.1 & 1.7 & - & 2.2 & 1.8 & 0.9 & - & - & 1.4 & - & - \\
\hline Quinqueloculina seminula & - & 3.3 & - & 3.2 & - & 1.6 & - & 3.0 & 0.1 & 2.1 & 0.1 & 1.6 & 0.5 & 0.9 & 1.4 & 6.3 & 8.0 & 1.4 & 1.6 & 2.4 \\
\hline Quinqueloculina tenuicollis & - & - & - & - & - & & - & - & - & - & - & - & - & - & - & - & - & - & - & - \\
\hline Triloculina trigonula & 0 & 0.4 & - & - & & & - & - & 0 & 0.5 & - & - & - & - & - & - & - & - & - & - \\
\hline Bigenerina nodosaria & - & - & - & 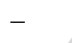 & & & - & - & - & - & - & - & - & - & - & - & 0.2 & - & - & - \\
\hline Textularia agglutinans & 0.6 & 1.6 & - & . & & - & 0.2 & 1.5 & 1.8 & 3.7 & 0.1 & 1.6 & 0.4 & 0.9 & 3.7 & 9.4 & 18.1 & 7.1 & 2.8 & 6.7 \\
\hline Stations & M13 & & $\overline{\mathrm{M} 1}$ & & M15 & & M16 & & M18 & & M19 & & M20 & & M22 & & M23 & & M24 & \\
\hline$\%$ Fossilising fauna & $L$ & $\mathrm{D}$ & $L$ & $\mathrm{D}$ & $L$ & $\mathrm{D}$ & $L$ & $\mathrm{D}$ & $L$ & $\mathrm{D}$ & $L$ & $\mathrm{D}$ & $L$ & $\mathrm{D}$ & $L$ & $\mathrm{D}$ & $L$ & $\mathrm{D}$ & $L$ & $\mathrm{D}$ \\
\hline Ammonia spp & - & 0.7 & - & - & - & - & - & - & - & - & - & - & - & - & - & - & - & - & - & - \\
\hline Ammonia beccarii f. inflata & 1.4 & 2.1 & 2.7 & 5.0 & 5.6 & 1.6 & 3.0 & 2.8 & 1.6 & 3.7 & 3.3 & 3.3 & 5.8 & 4.4 & 6.0 & 4.7 & 13.1 & 2.7 & 8.1 & 2.7 \\
\hline Bolivina alata & 0.1 & & & - & 0.2 & - & 3.2 & 0.6 & 0.3 & 0.7 & 0.7 & 1.1 & 2.4 & 1.1 & 0.1 & 0.8 & 4.3 & 0.5 & 4.5 & 1.0 \\
\hline Bulimina aculeata & 3.5 & 2.1 & 8.5 & 1.4 & 10.4 & 3.1 & 11.6 & 6.7 & 6.9 & 4.7 & 16.2 & 7.0 & 11.8 & 8.9 & 5.5 & 11.1 & $1-$ & 13.5 & 19.9 & 10.5 \\
\hline Bulimina elongata & 0.3 & 1.0 & - & 0.9 & - & - & - & 0.9 & - & - & - & - & - & - & - & - & - & - & - & - \\
\hline Bulimina marginata & 1.0 & 4.5 & 0.7 & 6.0 & 0.6 & 6.2 & 1.1 & 9.2 & 0.7 & $1-$ & 0.4 & 1- & 1.0 & 5.9 & 1.2 & 6.4 & 0.4 & 8.9 & - & 9.2 \\
\hline Cassidulina carinata & 2.1 & 31.1 & 14.5 & 29.8 & 24.5 & 44.6 & 18.6 & 27.3 & 17.6 & 34.2 & 47.7 & 17.0 & 15.8 & 21.1 & 38.3 & 30.6 & 22.9 & 28.3 & 17.5 & 26.5 \\
\hline Elphidium spp. & 0.5 & 1.7 & 0.5 & 0.9 & 0.1 & - & 0.2 & 1.2 & - & 0.7 & 0.2 & 0.4 & - & - & 3.1 & 2.2 & 0.7 & 0.8 & 0.4 & - \\
\hline Hyalinea balthica & 0.1 & 2.8 & 0.3 & 3.2 & 1.2 & 5.2 & 1.7 & 7.7 & 0.8 & 4.3 & 3.2 & 8.5 & 3.5 & 5.9 & 1.8 & 9.2 & 1.7 & 7.8 & 2.0 & 7.1 \\
\hline Melonis barleeanus & - & - & - & - & 0.1 & 0.5 & 1.7 & 1.8 & 0.1 & 0.3 & 0.5 & 2.6 & 7.2 & 1.1 & 0.4 & 0.3 & 3.0 & 1.3 & 2.4 & 2.7 \\
\hline Nonion fabum & 66.0 & 9.0 & 48.3 & 8.3 & 29.5 & 5.2 & 7.4 & 0.9 & 42.0 & 5.3 & 1.3 & 5.9 & 3.1 & 3.7 & 17.0 & 5.8 & 8.0 & 2.4 & 7.1 & 1.0 \\
\hline Nonionella turgida & 10.1 & 4.5 & 4.9 & 1.8 & 2.9 & 1.6 & 3.1 & 0.9 & 4.0 & 2.0 & 1.4 & 0.4 & 0.7 & 1.5 & 16.9 & 1.4 & 1.7 & 0.3 & 1.8 & 0.7 \\
\hline Pseudoeponides falsobec & 0.2 & 2.1 & 0.1 & 1.8 & 0.6 & 3.1 & 1.5 & 3.1 & 0.8 & 5.6 & 0.6 & 2.2 & 2.1 & 2.2 & 2.3 & 3.6 & 4.2 & 5.1 & 0.3 & 2.4 \\
\hline Rectuvigerina phlegeri & 8.2 & 4.2 & 8.0 & 1.8 & 4.6 & 1.0 & 2.5 & 0.9 & 4.6 & 0.7 & 0.2 & - & 1.0 & 0.4 & 0.4 & 0.6 & 1.0 & - & 0.7 & - \\
\hline Valvulineria bradyana & 4.3 & 19.7 & 7.9 & 21.1 & 13.4 & 10.9 & 27.0 & 9.2 & 15.6 & 12.6 & 4.6 & 11.8 & 19.4 & 14.1 & 2.7 & 7.8 & 15.2 & 8.1 & 18.3 & 7.8 \\
\hline Pyrgo oblonga & - & 0.7 & 0.1 & 0.5 & - & - & - & 0.3 & - & - & - & - & - & - & - & - & - & - & - & - \\
\hline Quinqueloculina lata & - & - & - & - & - & - & - & - & - & - & - & - & - & - & - & - & - & - & - & - \\
\hline Quinqueloculina seminula & - & 0.3 & 0.7 & 0.5 & 0.5 & 0.5 & 7.6 & 2.5 & 1.5 & 1.3 & 3.5 & 5.5 & 1.4 & 4.8 & 0.8 & 0.8 & 1.8 & 2.4 & 2.5 & 3.1 \\
\hline Quinqueloculina tenuicollis & - & - & - & - & - & - & - & - & - & - & - & - & - & - & - & - & - & - & - & - \\
\hline Triloculina trigonula & - & - & - & - & - & - & - & - & - & - & - & - & - & - & - & - & - & - & - & - \\
\hline Bigenerina nodosaria & - & - & - & - & 0.1 & - & 0.2 & 3.4 & - & - & 0.9 & 4.4 & 4.9 & 4.4 & 0.1 & 0.3 & 0.9 & 3.0 & 1.2 & 1.7 \\
\hline Textularia agglutinans & 1.1 & 3.1 & 0.2 & 0.9 & 2.0 & 1.0 & 0.5 & 5.5 & 0.7 & 3.7 & 7.3 & 2.6 & 10.8 & 6.3 & 0.7 & 2.8 & 2.7 & 3.2 & 2.1 & 1.4 \\
\hline
\end{tabular}

*Note that Mojtahid et al. (2009) grouped Ammonia tepida and Ammonia beccarii f. beccarii together as Ammonia spp. 
Table 4

Relative abundances of fossilising major species in the living ("L"; Goineau et al., 2011) and the dead ("D") faunas (this study) of September 2006. Grey boxes: percentages $\geq 2.5 \%$; Bold values: percentages $\geq 5 \%$.

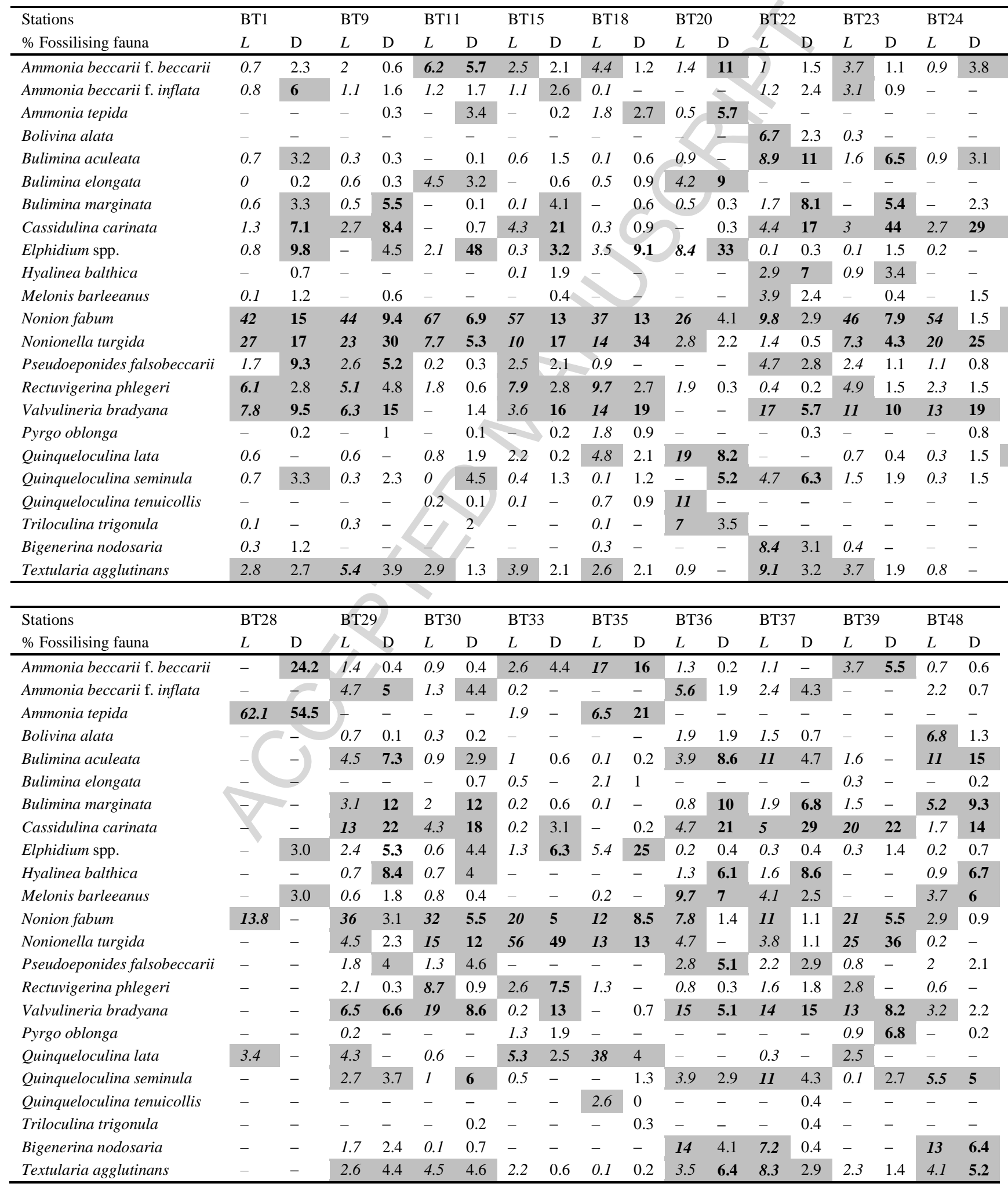


Table 5

$\mathrm{L} /(\mathrm{L}+\mathrm{D})$ ratios of major fossilising taxa in June 2005. $\mathrm{L} / \mathrm{L}+\mathrm{D})$ ratios were calculated for species $\geq 2.5 \%$ in the living and/or the dead faunas. Light grey boxes indicate $\mathrm{L} /(\mathrm{L}+\mathrm{D})$ values $<0.5$ (higher $\%$ in dead faunas); Black boxes correspond to values $\geq 0.5$ (higher $\%$ in living faunas); Italicised values range between 0.4 and 0.6 .

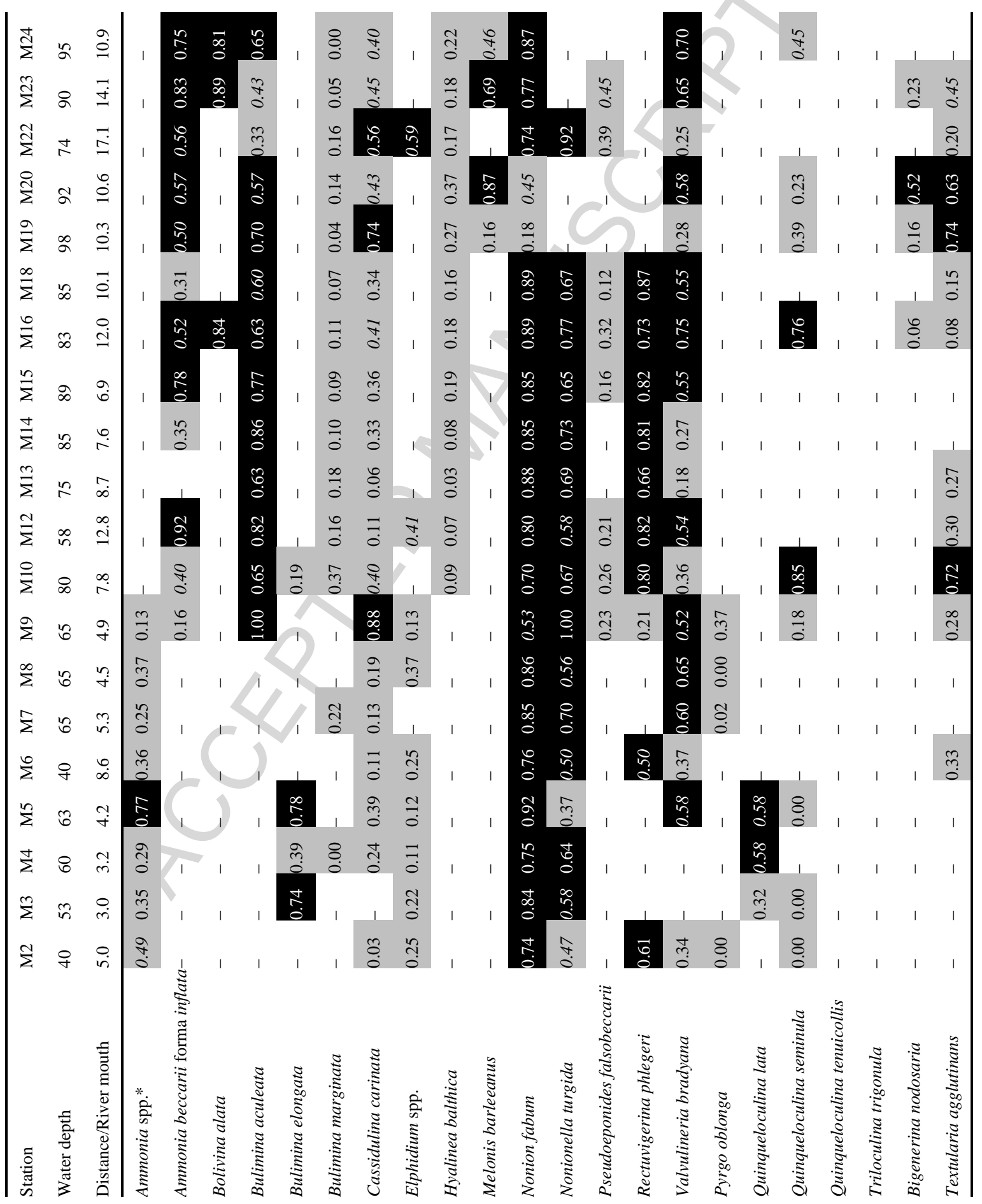

*Note that Mojtahid et al. (2009) grouped Ammonia tepida and Ammonia beccarii f. beccarii together as Ammonia spp. 
Table 6

$\mathrm{L} /(\mathrm{L}+\mathrm{D})$ ratios of major fossilising taxa in September 2006. $\mathrm{L} /(\mathrm{L}+\mathrm{D})$ ratios were calculated for species $\geq 2.5 \%$ in the living and/or the dead faunas. Light grey boxes indicate $L /(L+D)$ values $<0.5$ (higher $\%$ in dead faunas); Black boxes correspond to values $\geq 0.5$ (higher $\%$ in living faunas); Italicised values are ratios ranging between 0.4 and 0.6.

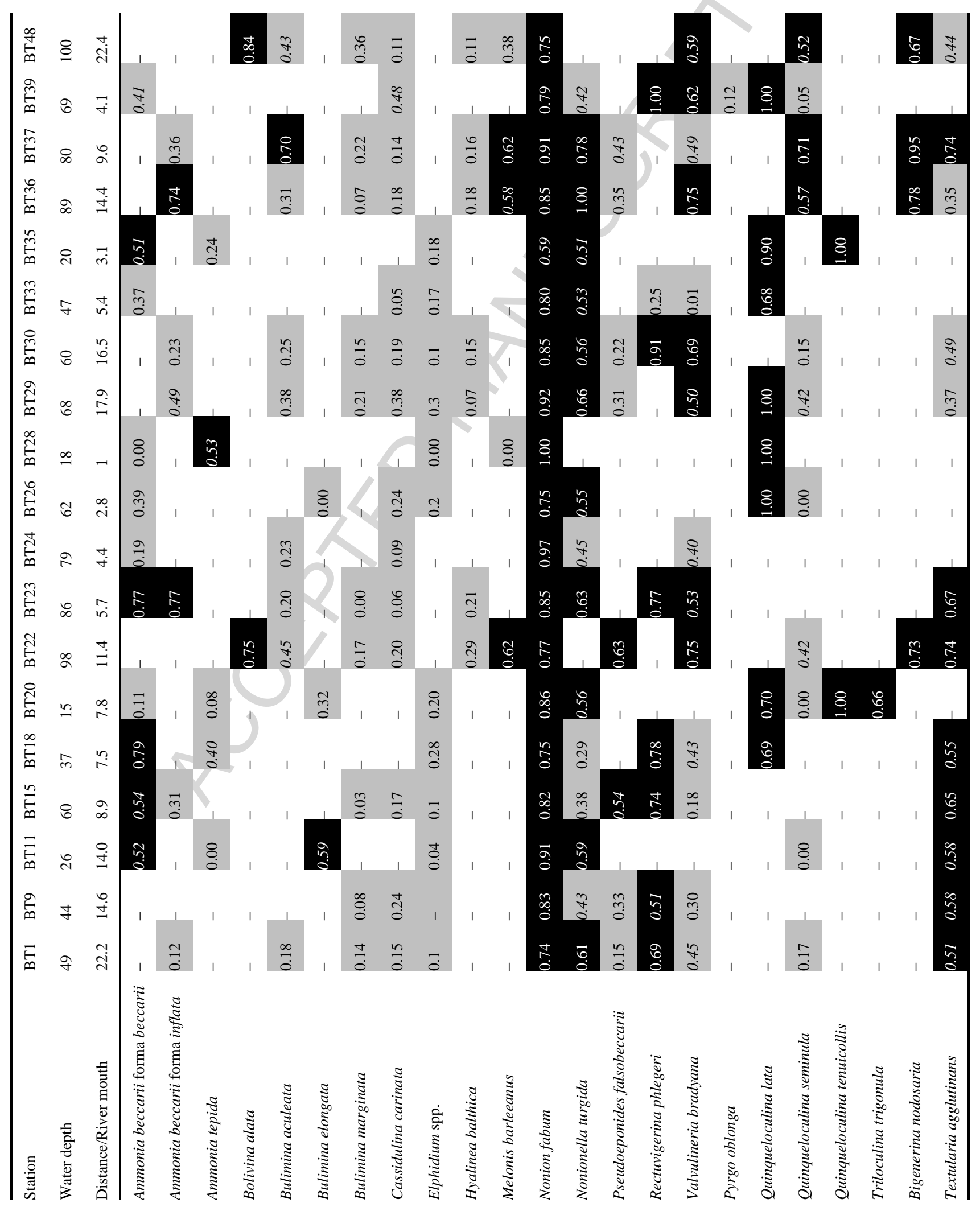


Table 7

Pearson correlation coefficients calculated between living and dead fossilising faunas of June 2005 and September 2006, separately. Grey boxes indicate correlation coefficients with $\mathrm{p}<$ 0.05 .

\begin{tabular}{llllll} 
& \multicolumn{2}{l}{ June 2005} & \multicolumn{2}{l}{ September 2006 } \\
\cline { 2 - 6 } Taxa & $\mathrm{r}$ & $p$ & $\mathrm{r}$ & $p$ \\
\hline Ammonia. beccarii f. beccarii & $n d$ & $n d$ & 0.75 & 0.0003 \\
Ammonia tepida & $n d$ & $n d$ & 0.91 & 0.0000 \\
\hline \hline Total Cluster 1 & 0.74 & 0.0002 & 0.89 & 0.0000 \\
\hline & & & & \\
\hline Bulimina elongata & 0.66 & 0.0015 & 0.78 & 0.0002 \\
Elphidium spp. & 0.78 & 0.00005 & 0.69 & 0.0017 \\
Quinqueloculina lata & 0.89 & 0.0000 & 0.70 & 0.0012 \\
\hline \hline Total Cluster 2 & 0.96 & 0.0000 & 0.67 & 0.0023 \\
\hline & & & & \\
\hline Nonion fabum & 0.53 & 0.0168 & 0.52 & 0.0258 \\
Rectuvigerina phlegeri & 0.42 & 0.0683 & 0.38 & 0.1167 \\
Valvulineria bradyana & 0.36 & 0.1238 & 0.43 & 0.0765 \\
\hline \hline Total Cluster 3 & 0.62 & 0.0038 & 0.63 & 0.005 \\
\hline & & & & \\
\hline Ammonia beccarii f. inflata & 0.30 & 0.2004 & 0.46 & 0.0554 \\
Bigenerina nodosaria & 0.71 & 0.0005 & 0.87 & 0.0000 \\
Bulimina aculeata & 0.73 & 0.0003 & 0.80 & 0.00006 \\
Bulimina marginata & 0.06 & 0.7986 & 0.66 & 0.003 \\
Hyalinea balthica & 0.82 & 0.00001 & 0.81 & 0.00004 \\
Melonis barleeanus & 0.46 & 0.0396 & 0.90 & 0.0000 \\
Pseudoeponides falscobeccarii & 0.72 & 0.0003 & 0.51 & 0.0324 \\
Quinqueloculina seminula & 0.12 & 0.6195 & 0.42 & 0.082 \\
Textularia agglutinans & 0.57 & 0.0088 & 0.54 & 0.022 \\
\hline \hline Total Cluster 4 & 0.88 & 0.0000 & 0.86 & 0.00001 \\
\hline & & & & \\
\hline Cassidulina carinata & 0.29 & 0.2193 & 0.44 & 0.0708 \\
Nonionella turgida & 0.80 & 0.0000 & 0.91 & 0.0000 \\
Pyrgo oblonga & 0.30 & 0.1993 & 0.51 & 0.0299 \\
\hline & & & &
\end{tabular}

